\title{
LEVEL II SCOUR ANALYSIS FOR BRIDGE 32 (SHRETH00060032) on TOWN HIGHWAY 6, crossing SARGENT BROOK, SHREWSBURY, VERMONT
}

Open-File Report 98-299

Prepared in cooperation with

VERMONT AGENCY OF TRANSPORTATION

and

FEDERAL HIGHWAY ADMINISTRATION

U.S. Department of the Interior

U.S. Geological Survey

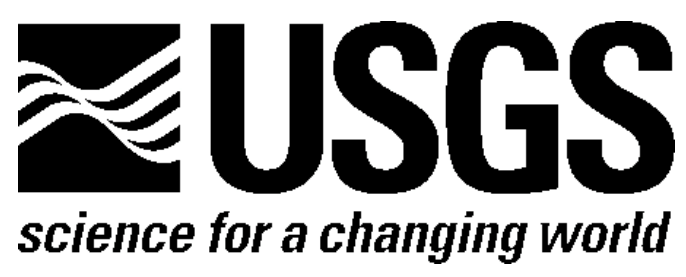


LEVEL II SCOUR ANALYSIS FOR

BRIDGE 32 (SHRETH00060032) on

TOWN HIGHWAY 6, crossing

SARGENT BROOK,

SHREWSBURY, VERMONT

By RONDA L. BURNS and ERICK M. BOEHMLER

U.S. Geological Survey

Open-File Report 98-299

Prepared in cooperation with

VERMONT AGENCY OF TRANSPORTATION

and

FEDERAL HIGHWAY ADMINISTRATION 


\title{
U.S. DEPARTMENT OF THE INTERIOR BRUCE BABBITT, Secretary
}

\author{
U.S. GEOLOGICAL SURVEY
}

Thomas J. Casadevall, Acting Director

For additional information write to:

District Chief

U.S. Geological Survey 361 Commerce Way

Pembroke, NH 03275-3718
Copies of this report may be purchased from:

U.S. Geological Survey

Branch of Information Services

Open-File Reports Unit

Box 25286

Denver, CO 80225-0286 


\section{CONTENTS}

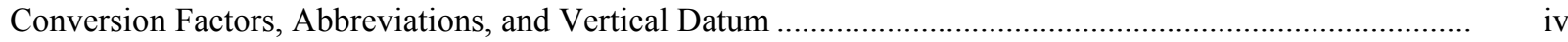

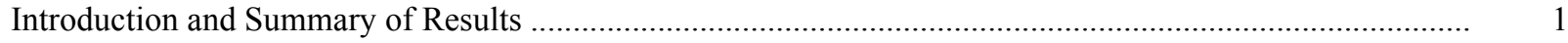

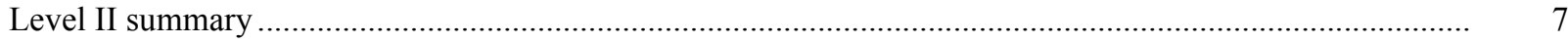

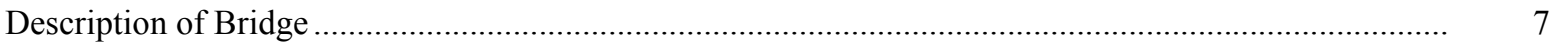

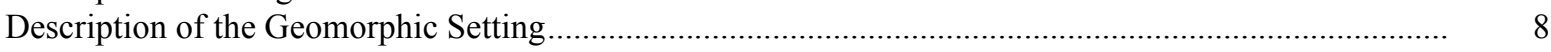

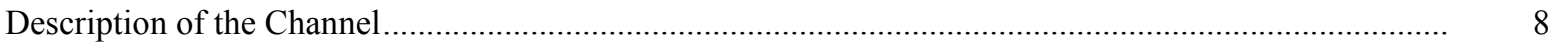

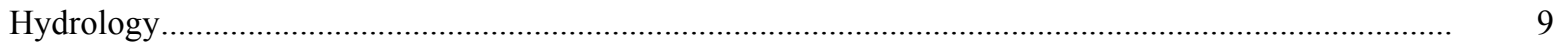

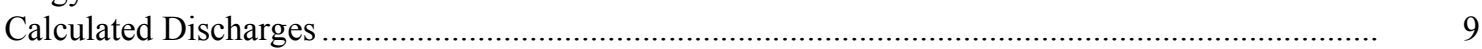

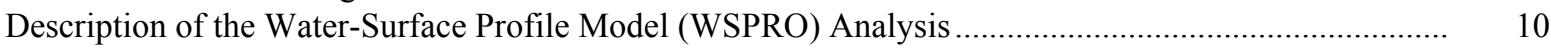

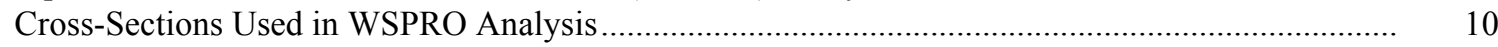

Data and Assumptions Used in WSPRO Model ........................................................................ 11

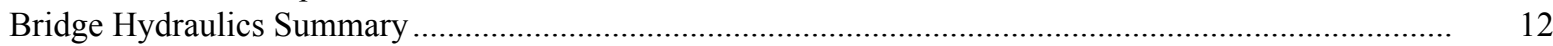

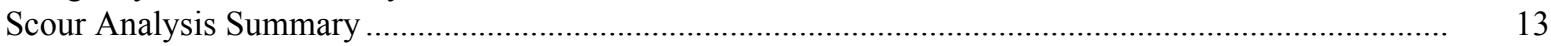

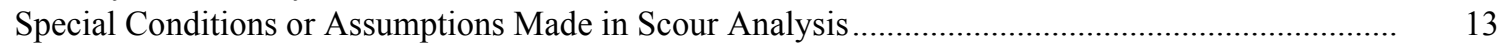

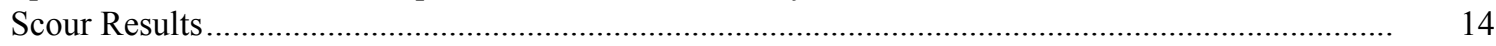

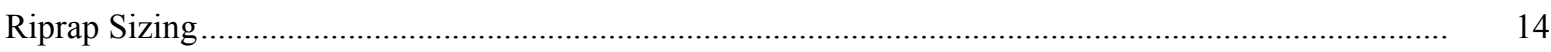

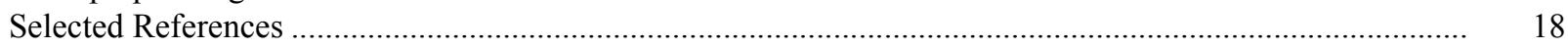

Appendices:

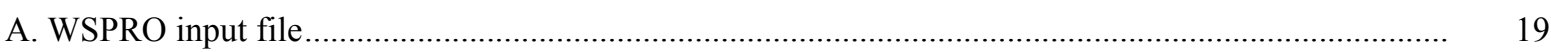

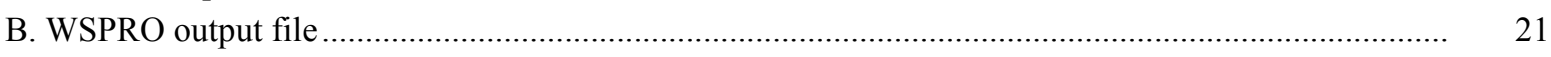

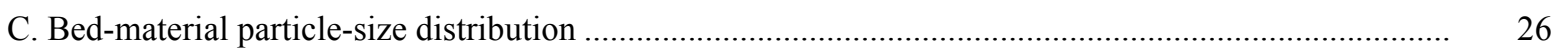

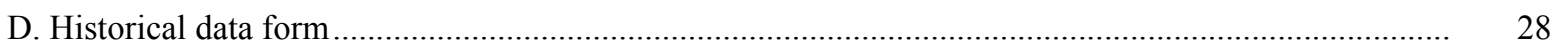

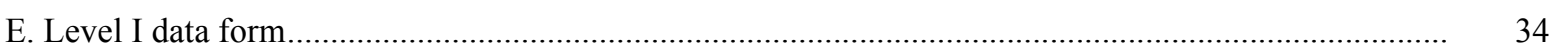

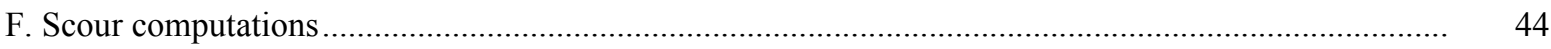

\section{FIGURES}

1. Map showing location of study area on USGS 1:24,000 scale map

2. Map showing location of study area on Vermont Agency of Transportation town highway map

3. Structure SHRETH00060032 viewed from upstream (September 28, 1995 )...

4. Downstream channel viewed from structure SHRETH00060032 (September 28, 1995).........................

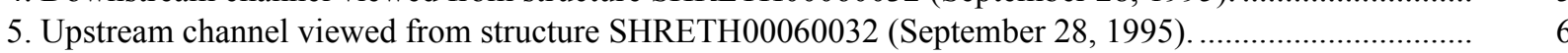

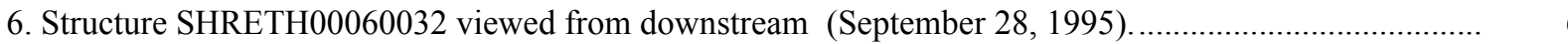

7. Water-surface profiles for the 100- and 500-year discharges at structure

SHRETH00060032 on Town Highway 6, crossing Sargent Brook,

Shrewsbury, Vermont

8. Scour elevations for the 100- and 500-year discharges at structure

SHRETH00060032 on Town Highway 6, crossing Sargent Brook,

Shrewsbury, Vermont.

\section{TABLES}

1. Remaining footing/pile depth at abutments for the 100-year discharge at structure

SHRETH00060032 on Town Highway 6, crossing Sargent Brook,

Shrewsbury, Vermont

2. Remaining footing/pile depth at abutments for the 500-year discharge at structure

SHRETH00060032 on Town Highway 6, crossing Sargent Brook,

Shrewsbury, Vermont 


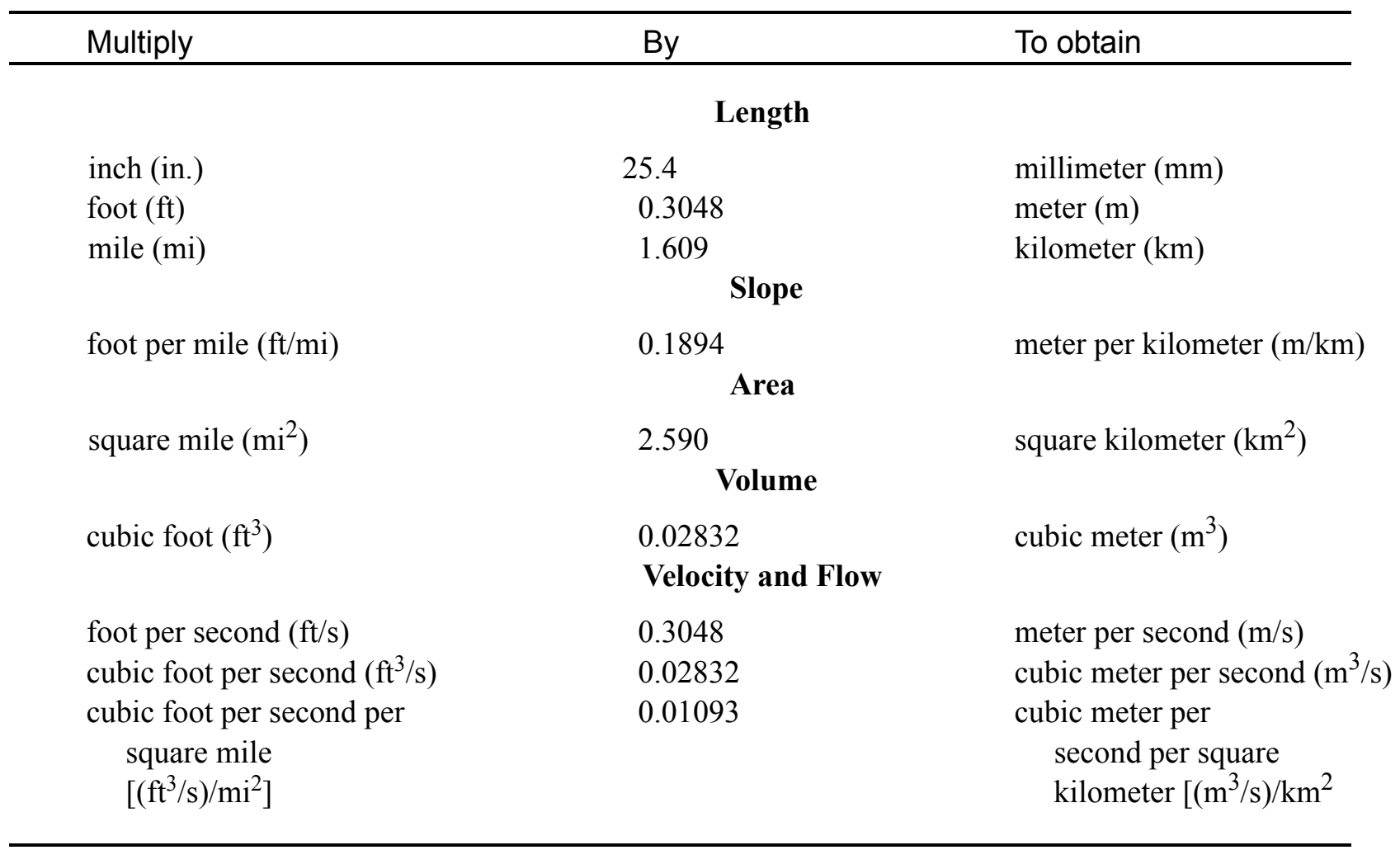

\section{OTHER ABBREVIATIONS}

$\begin{array}{lrlr}\mathrm{BF} & \text { bank full } & \text { LWW } & \text { left wingwall } \\ \mathrm{cfs} & \text { cubic feet per second } & \text { Max } & \text { maximum } \\ \mathrm{D}_{50} & \text { median diameter of bed material } & \text { MC } & \text { main channel } \\ \mathrm{DS} & \text { downstream } & \text { RAB } & \text { right abutment } \\ \mathrm{elev} & \text { elevation } & \text { RABUT } & \text { face of right abutment } \\ \mathrm{f} / \mathrm{p} & \text { flood plain } & \text { RB } & \text { right bank } \\ \mathrm{ft} & \text { square feet } & \text { ROB } & \text { right overbank } \\ \mathrm{ft} / \mathrm{ft} & \text { feet per foot } & \text { RWW } & \text { right wingwall } \\ \mathrm{FEMA} & \text { Federal Emergency Management Agency } & \text { TH } & \text { town highway } \\ \mathrm{FHWA} & \text { Federal Highway Administration } & \text { UB } & \text { under bridge } \\ \mathrm{JCT} & \text { junction } & \text { US } & \text { upstream } \\ \text { LAB } & \text { left abutment } & \text { USGS } & \text { United States Geological Survey } \\ \text { LABUT } & \text { face of left abutment } & \text { VTAOT } & \text { Vermont Agency of Transportation } \\ \text { LB } & \text { left bank } & \text { WSPRO } & \text { water-surface profile model } \\ \text { LOB } & \text { left overbank } & \text { yr } & \text { year }\end{array}$

In this report, the words "right" and "left" refer to directions that would be reported by an observer facing downstream. Sea level: In this report, "sea level" refers to the National Geodetic Vertical Datum of 1929-- a geodetic datum derived from a general adjustment of the first-order level nets of the United States and Canada, formerly called Sea Level Datum of 1929.

In the appendices, the above abbreviations may be combined. For example, USLB would represent upstream left bank. 


\title{
LEVEL II SCOUR ANALYSIS FOR BRIDGE 32 (SHRETH00060032) ON TOWN HIGHWAY 6, CROSSING SARGENT BROOK, SHREWSBURY, VERMONT
}

\author{
By Ronda L. Burns and Erick M. Boehmler
}

\section{INTRODUCTION AND SUMMARY OF RESULTS}

This report provides the results of a detailed Level II analysis of scour potential at structure SHRETH00060032 on Town Highway 6 crossing Sargent Brook, also referred to as Branch of Cold River, Shrewsbury, Vermont (figures 1-8). A Level II study is a basic engineering analysis of the site, including a quantitative analysis of stream stability and scour (FHWA, 1993). Results of a Level I scour investigation also are included in appendix E of this report. A Level I investigation provides a qualitative geomorphic characterization of the study site. Information on the bridge, gleaned from Vermont Agency of Transportation (VTAOT)

files, was compiled prior to conducting Level I and Level II analyses and is found in appendix D.

The site is in the Green Mountain section of the New England physiographic province in south-central Vermont. The $6.34-\mathrm{mi}^{2}$ drainage area is in a predominantly rural and forested basin. In the vicinity of the study site, the surface cover is forest.

In the study area, Sargent Brook has an incised, sinuous channel with a slope of approximately $0.04 \mathrm{ft} / \mathrm{ft}$, an average channel top width of $55 \mathrm{ft}$ and an average bank height of $3 \mathrm{ft}$. The channel bed material ranges from sand to boulders with a median grain size $\left(\mathrm{D}_{50}\right)$ of $106.0 \mathrm{~mm}(0.348 \mathrm{ft})$. The geomorphic assessment at the time of the Level I and Level II site visit on September 28, 1995, indicated that the reach was stable.

The Town Highway 6 crossing of Sargent Brook is a 36-ft-long, one-lane bridge consisting of one 33-foot steel-stringer span (Vermont Agency of Transportation, written communication, March 15, 1995). The opening length of the structure parallel to the bridge face is $31.9 \mathrm{ft}$. The bridge is supported by vertical, concrete abutments with wingwalls. The channel is not skewed to the opening and the opening-skew-to-roadway is zero degrees.

During the Level I assessment, it was observed that the footings on the right abutment and downstream right wingwall were exposed up to $0.5 \mathrm{ft}$. Scour countermeasures at the site included type- 2 stone fill (less than 36 inches diameter) along the left abutment, the downstream left wingwall, and at the downstream end of the downstream right wingwall. Type-3 stone fill (less than 48 inches diameter) was observed along the upstream right bank and the upstream left and right wingwalls. Additional details describing conditions at the site are included in the Level II Summary and appendices D and E. 
Scour depths and recommended rock rip-rap sizes were computed using the general guidelines described in Hydraulic Engineering Circular 18 (Richardson and Davis, 1995) for the 100- and 500-year discharges. Total scour at a highway crossing is comprised of three components: 1) long-term streambed degradation; 2) contraction scour (due to accelerated flow caused by a reduction in flow area at a bridge) and; 3 ) local scour (caused by accelerated flow around piers and abutments). Total scour is the sum of the three components. Equations are available to compute depths for contraction and local scour and a summary of the results of these computations follows.

Contraction scour for all modelled flows ranged from 0.3 to $1.0 \mathrm{ft}$. The worst-case contraction scour occurred at the 500-year discharge. Left abutment scour ranged from 6.1 to $7.8 \mathrm{ft}$ and right abutment scour ranged from 13.2 to $17.5 \mathrm{ft}$. The worst-case abutment scour occurred at the 500-year discharge. Additional information on scour depths and depths to armoring are included in the section titled "Scour Results". Scoured-streambed elevations, based on the calculated scour depths, are presented in tables 1 and 2. A crosssection of the scour computed at the bridge is presented in figure 8. Scour depths were calculated assuming an infinite depth of erosive material and a homogeneous particle-size distribution.

It is generally accepted that the Froehlich equation (abutment scour) gives "excessively conservative estimates of scour depths" (Richardson and Davis, 1995, p. 46). Usually, computed scour depths are evaluated in combination with other information including (but not limited to) historical performance during flood events, the geomorphic stability assessment, existing scour protection measures, and the results of the hydraulic analyses. Therefore, scour depths adopted by VTAOT may differ from the computed values documented herein. 


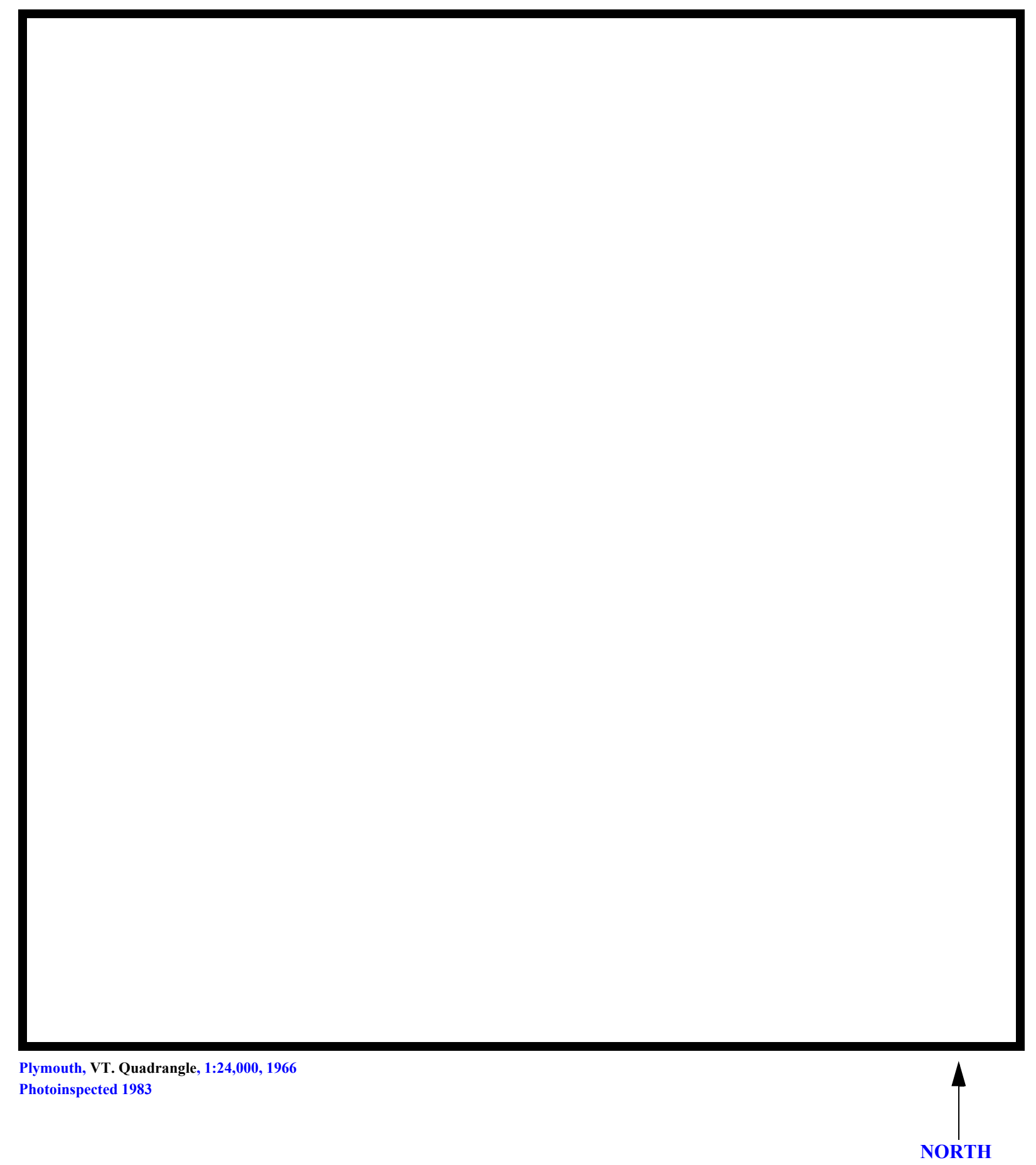

Figure 1. Location of study area on USGS 1:24,000 scale map. 
Figure 2. Location of study area on Vermont Agency of Transportation town highway map. 

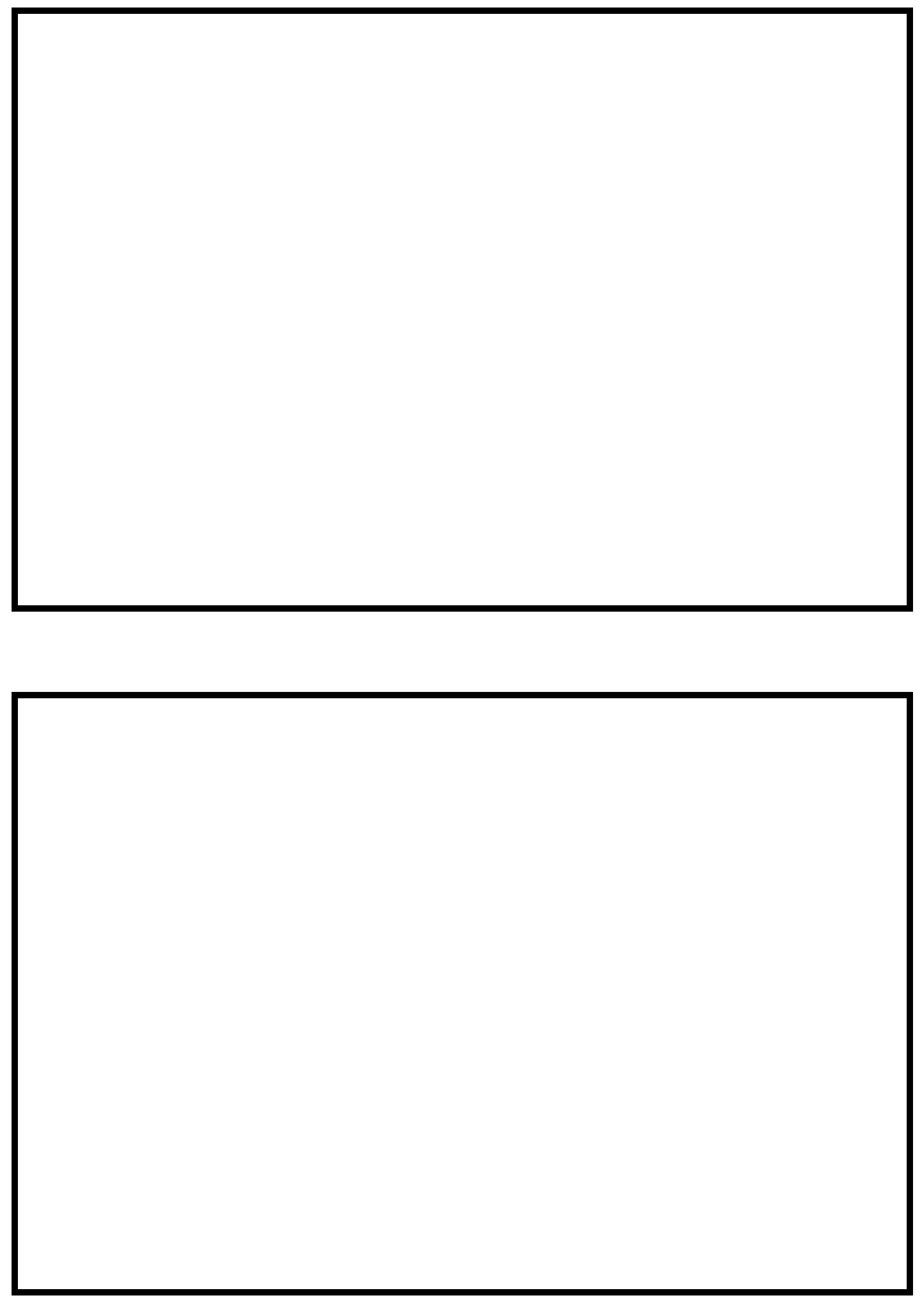

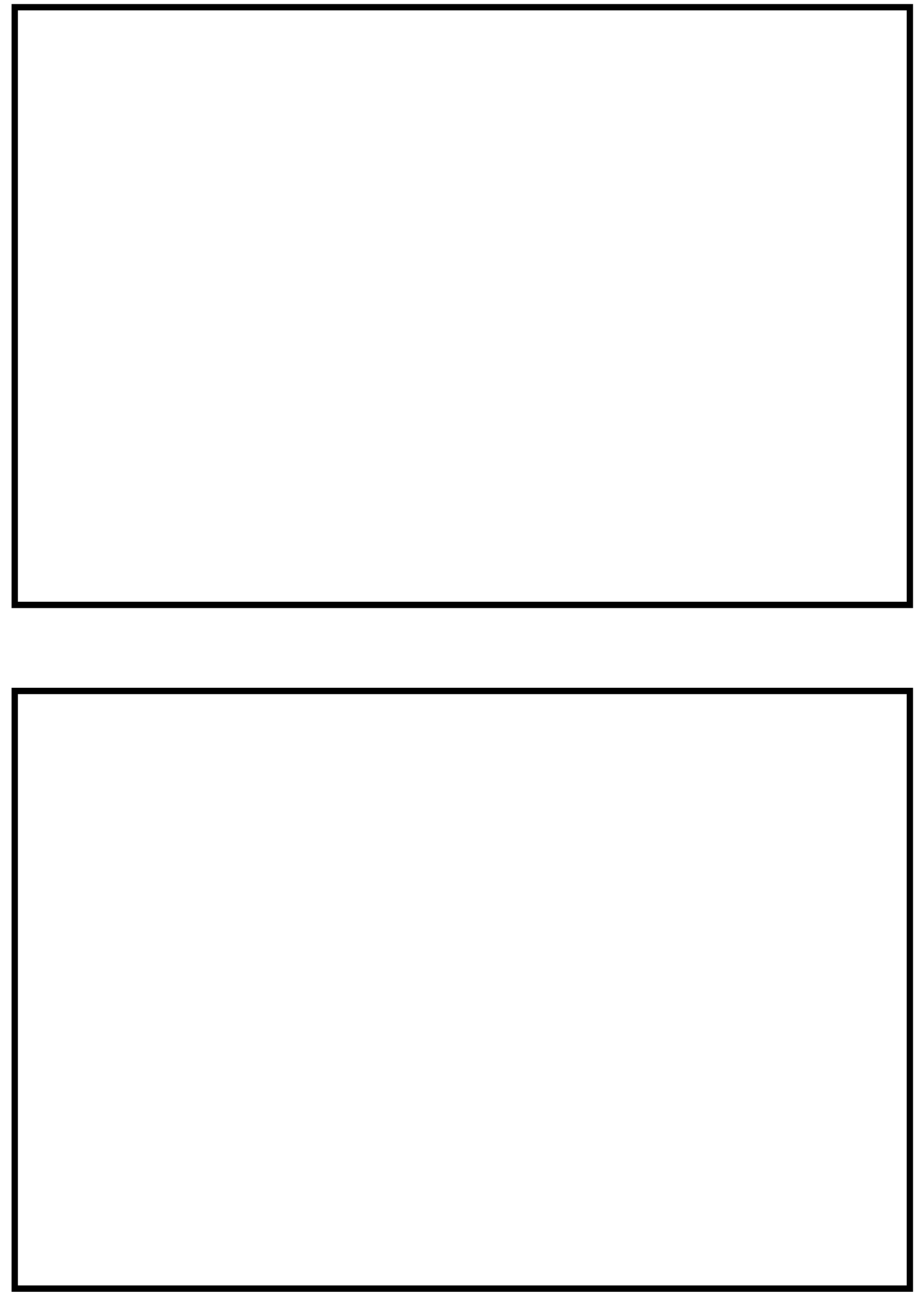


\section{LEVEL II SUMMARY}

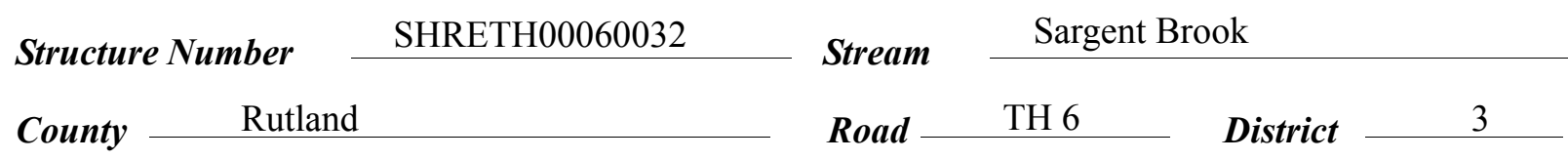

\section{Description of Bridge}

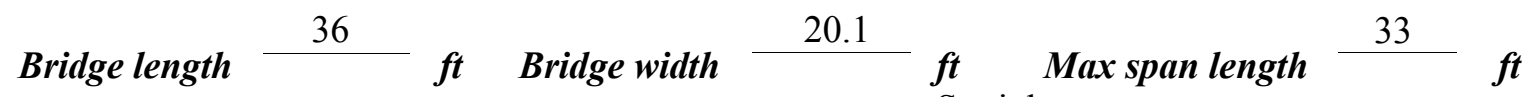
Alignment of bridge to road (on curve or straight) Abutment type Vertical, concrete

Stone fill on abutment?

\section{Embankment type} Straight

nammintinu af atom a fil Yes

nato af insnortion Sloping 9/28/95 downstream end of the downstream right wingwall. Type-3, along the upstream left and right wingwalls.

Abutments and wingwalls are concrete. The footings on the right abutment and downstream right wingwall are exposed up to $0.5 \mathrm{ft}$.

\begin{tabular}{|c|c|c|}
\hline & No & -- \\
\hline Is bridge skewed to flood flow according to Yes ' survey? & Angle & \\
\hline
\end{tabular}

Debris accumulation on bridge at time of Level I or Level II site visit:

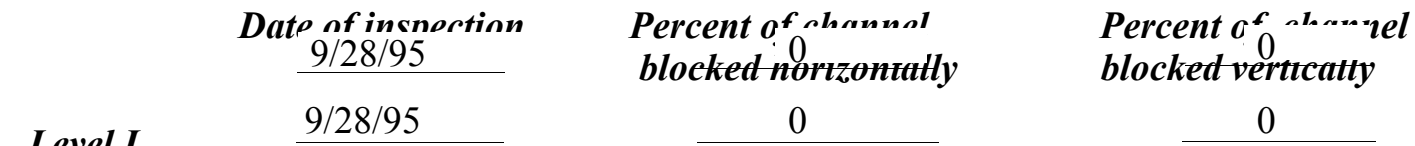

Level I

Moderate. There is some debris scattered in the channel

Level II downstream.

Potential for debris

A vegetated point bar, along the left bank and abutment, directed low flow towards the right Doscriho anv, foaturos noar ar at the hridoo that mav' affort flow, (includo ahsorvation datol abutment as of $9 / 28 / 95$. 


\section{Description of the Geomorphic Setting}

General topography The channel is located within a moderate relief valley with a narrow flood plain.

Geomorphic conditions at bridge site: downstream (DS), upstream (US)

Date of inspection $\quad 9 / 28 / 95$

DS left: $\quad$ Moderately sloped, irregular overbank

DS right: $\quad$ Steep valley wall

US left: $\quad$ Steep road embankment to a moderately sloped overbank

US right: $\quad$ Steep valley wall

\section{Description of the Channel}

$\begin{array}{llll}\text { Average top width } & 55 & \text { Average depth } & \frac{3}{\text { Cobbles/Gravel }} \text { Sand/Boulders }\end{array}$

Predominant bed material

Bank material

Sinuous and locally

braided with non-alluvial channel boundaries and narrow point bars.

$9 / 28 / 95$

Vegetative co 1 Trees

DS left: $\quad$ Trees

DS right: $\quad$ Trees and brush

US left: $\quad$ Trees

US right: $\quad$ Yes

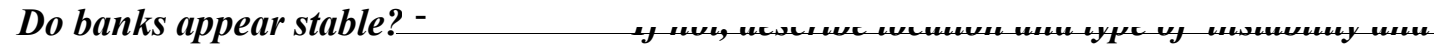

date of observation.

The assessment of

9/28/95 noted low flow conditions are influenced by a mid-channel bar in the downstream Describe any obstructions in channel and date of observation.

reach. 


\section{Hydrology}

Drainage area $\quad 6.34 \boldsymbol{m i}^{2}$

Percentage of drainage area in physiographic provinces: (approximate)

Physiographic province/section

New England/Green Mountain
Percent of drainage area 100
Is drainage area considered rural or urban?
Rural urbanization: None
Describe any significant

\section{Calculated Discharges $\quad 2,750$ \\ Q100 $\quad \mathrm{ft}^{3} / \mathrm{s}$ \\ $\quad \quad \mathrm{ft}^{3} / \mathrm{s}$}

The 100- and 500-year discharges are based on flood

frequency estimates available from the VTAOT database (written communication, May 1995). The values used were within a range defined by flood frequency curves developed from several empirical methods (Benson, 1962; Johnson and Tasker, 1974; FHWA, 1983; Potter, 1957a\&b; Talbot, 1887). Each curve was extended graphically to the 500 -year event. 


\section{Description of the Water-Surface Profile Model (WSPRO) Analysis}

Datum for WSPRO analysis (USGS survey, sea level, VTAOT plans)

VTAOT plans

Datum tie between USGS survey and VTAOT plans

The USGS arbitrary survey datum

was adjusted to the VTAOT plans' datum by subtracting $15.3 \mathrm{ft}$.

Description of reference marks used to determine USGS datum. $\quad$ RM1 is a chiseled X on top of the downstream end of the left abutment (elev. $485.08 \mathrm{ft}$, arbitrary survey datum). RM2 is a steel stake with a yellow cap, $7 \mathrm{ft}$ to the right and $14 \mathrm{ft}$ upstream of the right abutment (elev. $483.08 \mathrm{ft}$, arbitrary survey datum). RM3 is a nail, $5 \mathrm{ft}$ above the ground, in a telephone pole $20 \mathrm{ft}$ from the upstream end of the right abutment (elev. $490.69 \mathrm{ft}$, arbitrary survey datum).

\section{Cross-Sections Used in WSPRO Analysis}

\begin{tabular}{cccl}
\hline${ }^{1}$ Cross-section & $\begin{array}{c}\text { Section } \\
\text { Reference } \\
\text { Distance } \\
\text { (SRD) in feet }\end{array}$ & $\begin{array}{c}{ }^{2} \text { Cross-section } \\
\text { development }\end{array}$ & \multicolumn{1}{c}{ Comments } \\
\hline EXIT1 & -98 & 1 & Exit section \\
EXITX & -35 & 1 & $\begin{array}{l}\text { Exit section } \\
\text { Downstream Full-valley } \\
\text { section (Templated from }\end{array}$ \\
FULLV & 0 & 2 & $\begin{array}{l}\text { EXITX) } \\
\text { Bridge section }\end{array}$ \\
BRIDG & 0 & 1 & Road Grade section \\
RDWAY & 12 & 1 & Approach section \\
\hline
\end{tabular}

${ }^{1}$ For location of cross-sections see plan-view sketch included with Level I field form, Appendix E. For more detail on how cross-sections were developed see WSPRO input file. 


\section{Data and Assumptions Used in WSPRO Model}

Hydraulic analyses of the reach were done by use of the Federal Highway Administration's WSPRO step-backwater computer program (Shearman and others, 1986, and Shearman, 1990). The analyses reported herein reflect conditions existing at the site at the time of the study. Furthermore, in the development of the model it was necessary to assume no accumulation of debris or ice at the site. Results of the hydraulic model are presented in the Bridge Hydraulic Summary, appendix B, and figure 7.

Channel roughness factors (Manning's " $n$ ") used in the hydraulic model were estimated using field inspections at each cross section following the general guidelines described by Arcement and Schneider (1989). Final adjustments to the values were made during the modelling of the reach. Channel " $\mathrm{n}$ " values for the reach ranged from 0.050 to 0.065 , and the overbank "n" value was 0.080 .

Critical depth at the exit section (EXIT1) was assumed for the 100- and 500-year discharges as the starting water surface. Normal depth was computed below critical depth approximately $0.4 \mathrm{ft}$, by use of the slope-conveyance method outlined in the user's manual for WSPRO (Shearman, 1990). The slope used was $0.0380 \mathrm{ft} / \mathrm{ft}$, which was estimated from surveyed thalweg points downstream of the bridge.

The surveyed approach section (APPR1) was modelled one bridge length upstream of the upstream face, as recommended by Shearman and others (1986). This location provides a consistent method for determining scour variables.

For the 100- and 500-year discharges, WSPRO assumes critical depth at the bridge section. Supercritical models were developed for these discharges. After analyzing both the supercritical and subcritical profiles for each discharge, it was determined that the water surface

profile does pass through critical depth within the bridge opening. Thus, the assumptions of critical depth at the bridge are satisfactory solutions. 


\section{Bridge Hydraulics Summary}

\begin{tabular}{lll} 
Average bridge embankment elevation & \multicolumn{1}{c}{485.5} \\
Average low steel elevation & 482.7 & $\boldsymbol{f t}$
\end{tabular}

100-year discharge $\quad 1,800 \quad \mathrm{ft}^{3} / \mathrm{s}$

Water-surface elevation in bridge opening $\quad 475.2 \quad f t$

Road overtopping? ___ No Discharge over road ___ $\quad, 3 / s$

Area of flow in bridge opening $\quad 148 \quad \mathrm{ft}^{2}$

Average velocity in bridge opening $12.2 \mathrm{ft} / \mathrm{s}$

Maximum WSPRO tube velocity at bridge $\quad 15.4 \mathrm{ft} / \mathrm{s}$

Water-surface elevation at Approach section with bridge 478.3

Water-surface elevation at Approach section without bridge $\quad 476.7$

Amount of backwater caused by bridge $\quad 1.6 \quad$ it

500-year discharge $\quad 2,750 \quad \mathrm{ft}^{3} / \mathrm{s}$

Water-surface elevation in bridge opening $\quad 476.7$ ft

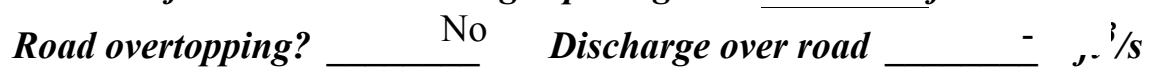

Area of flow in bridge opening $\quad 195 \quad \mathrm{ft}^{2}$

Average velocity in bridge opening $14.1 \mathrm{ft} / \mathrm{s}$

Maximum WSPRO tube velocity at bridge 18.1 's

Water-surface elevation at Approach section with bridge 480.6

Water-surface elevation at Approach section without bridge $\quad 477.9$

Amount of backwater caused by bridge $\quad 2.7, t$

Incipient overtopping discharge __ _ $\quad \mathrm{ft}^{3} / \mathrm{s}$

Water-surface elevation in bridge opening $\quad-\quad t$

Area of flow in bridge opening _ _ $\quad \mathrm{ft}^{2}$

Average velocity in bridge opening - $\quad \mathrm{ft} / \mathrm{s}$

Maximum WSPRO tube velocity at bridge $\quad-\quad f t / s$

Water-surface elevation at Approach section with bridge

Water-surface elevation at Approach section without bridge

Amount of backwater caused by bridge _ _ _ it 


\section{Scour Analysis Summary}

\section{Special Conditions or Assumptions Made in Scour Analysis}

Scour depths were computed using the general guidelines described in Hydraulic Engineering Circular 18 (Richardson and Davis, 1995). Scour depths were calculated assuming an infinite depth of erosive material and a homogeneous particle-size distribution. The results of the scour analyses for the 100- and 500-year discharges are presented in tables 1 and 2 and the scour depths are shown graphically in figure 8 .

Contraction scour for the 100- and 500-year discharges was computed by use of the Laursen clear-water contraction scour equation (Richardson and Davis, 1995, p. 32, equation 20). The streambed armoring depths computed suggest that armoring will not limit the depth of contraction scour.

Abutment scour was computed by use of the Froehlich equation (Richardson and Davis, 1995, p. 48, equation 28). Variables for the Froehlich equation include the Froude number of the flow approaching the embankments, the length of the embankment blocking flow, and the depth of flow approaching the embankment less any roadway overtopping.

Because the influence of scour processes on the stone fill embankment material along the left abutment is uncertain, the scour depth at the left vertical concrete abutment wall is unknown. Therefore, the total scour depth computed at the toe of the embankment was applied for the entire stone fill embankment as shown in fig. 8 . 


\section{Scour Results}

Contraction scour:

$\begin{array}{rrr}\text { 100-year } & \text { Incipient } \\ \text { discharge } & \text { discharge } & \text { overtopping } \\ \text { discharge }\end{array}$

(Scour depths in feet)

Main channel

Live-bed scour

Clear-water scour

Depth to armoring

Left overbank

Right overbank

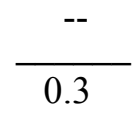

$17.0^{-}$
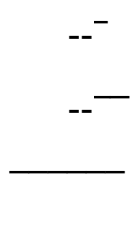

Local scour:

Abutment scour

Left abutment

Right abutment

Pier scour

Pier 1

Pier 2

Pier 3
6.1

13.2
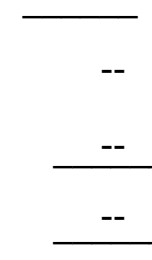

7.8

17.5

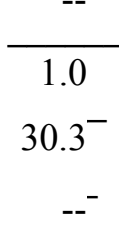

--

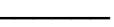




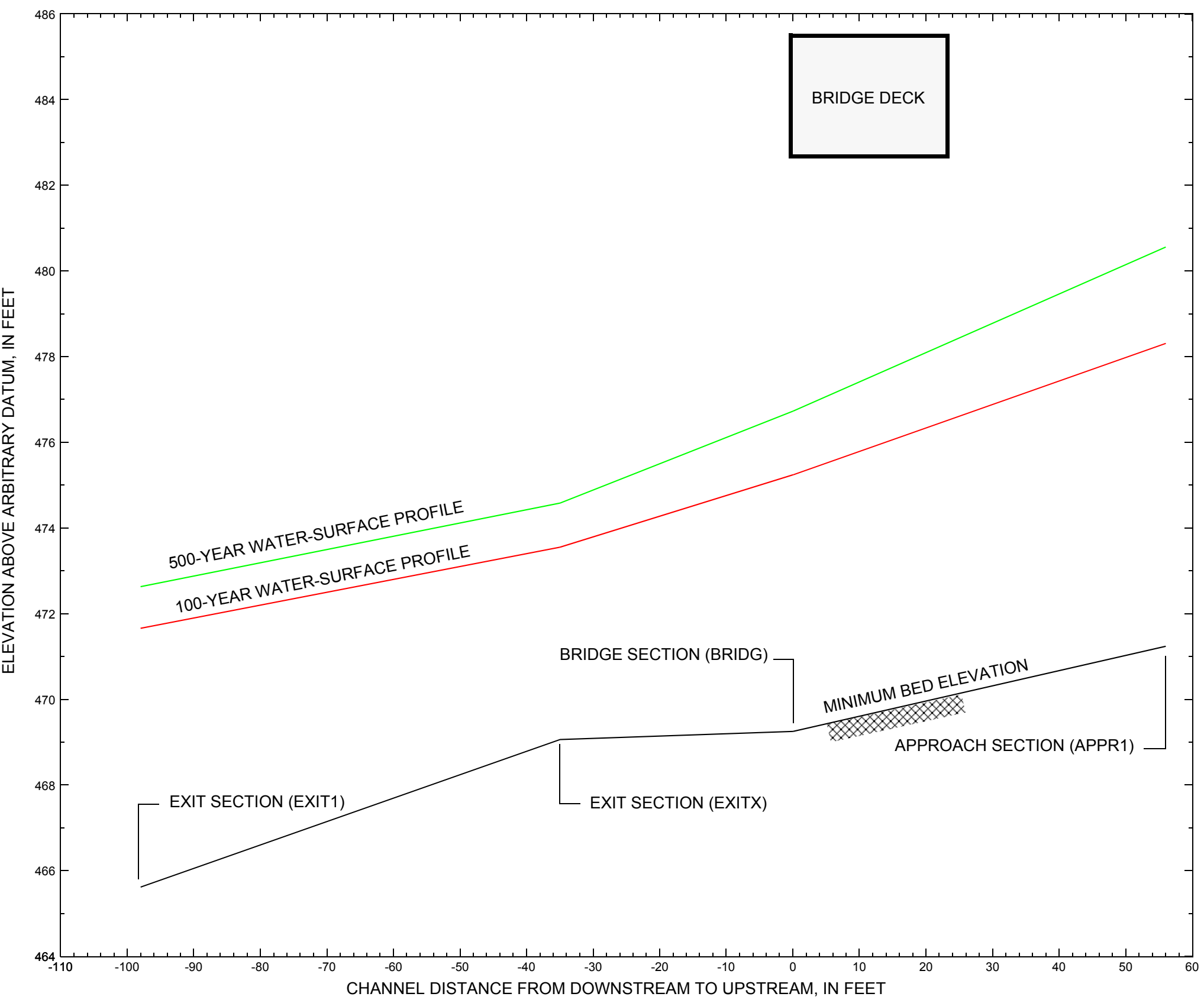

Figure 7. Water-surface profiles for the 100- and 500-year discharges at structure SHRETH00060032 on Town Highway 6, crossing Sargent Brook, Shrewsbury, Vermont. 


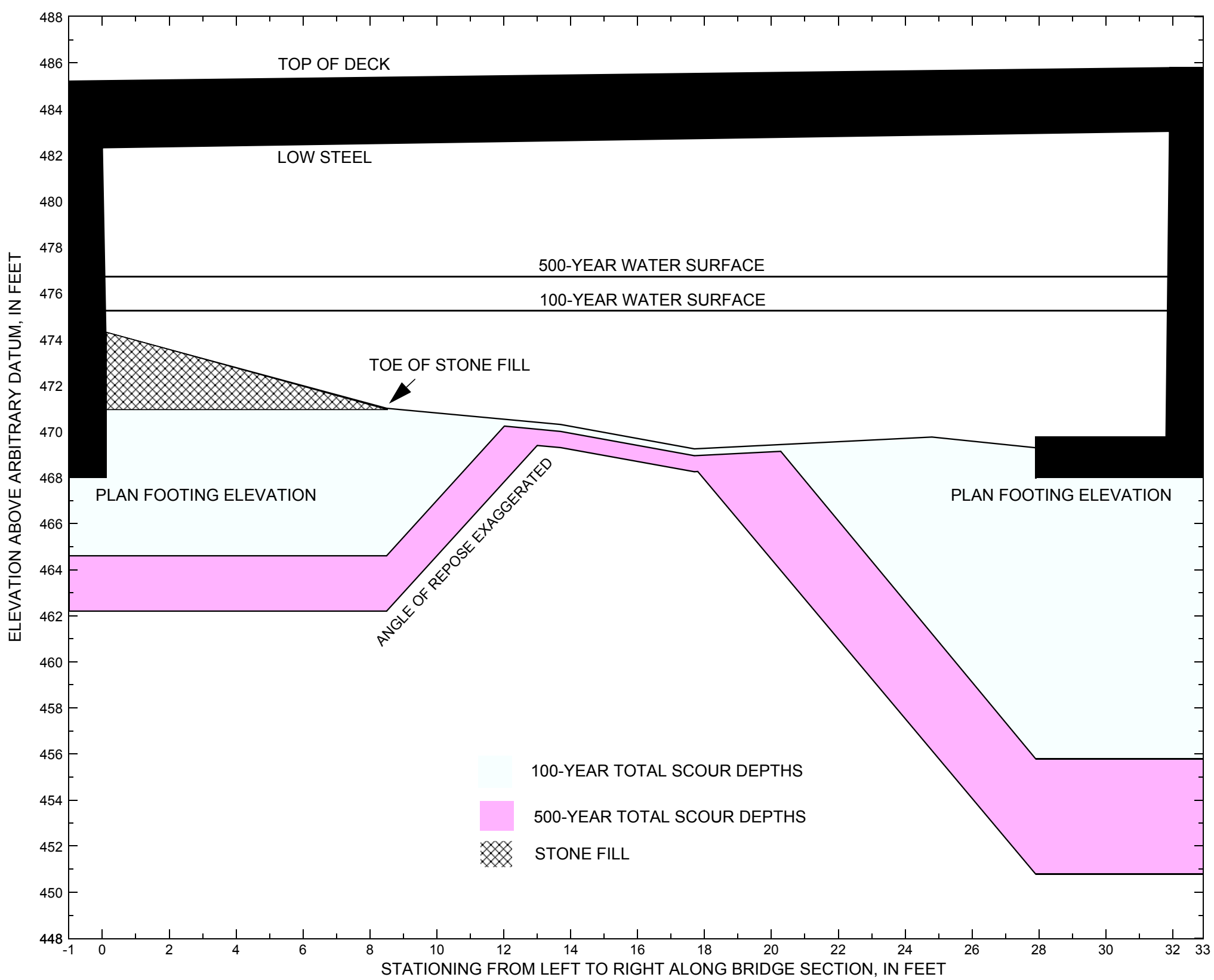

Figure 8. Scour elevations for the 100- and 500-year discharges at structure SHRETH00060032 on Town Highway 6, crossing Sargent Brook, Shrewsbury, Vermont. 
Table 1. Remaining footing/pile depth at abutments for the 100-year discharge at structure SHRETH00060032 on Town Highway 6, crossing Sargent Brook, Shrewsbury, Vermont.

[VTAOT, Vermont Agency of Transportation; --, no data]

\begin{tabular}{|c|c|c|c|c|c|c|c|c|c|c|c|}
\hline Description & Station $^{1}$ & $\begin{array}{l}\text { VTAOT } \\
\text { minimum } \\
\text { bridge seat } \\
\text { elevation } \\
\text { (feet) }\end{array}$ & $\begin{array}{l}\text { Surveyed } \\
\text { minimum } \\
\text { low-chord } \\
\text { elevation } \\
\quad \text { (feet) }\end{array}$ & $\begin{array}{c}\text { Bottom of } \\
\text { footing/pile } \\
\text { elevation }{ }^{2} \\
\text { (feet) }\end{array}$ & $\begin{array}{c}\text { Channel } \\
\text { elevation at } \\
\text { abutment/ } \\
\text { pier }^{2} \\
\text { (feet) }\end{array}$ & $\begin{array}{l}\text { Contraction } \\
\text { scour depth } \\
\text { (feet) }\end{array}$ & $\begin{array}{l}\text { Abutment } \\
\text { scour } \\
\text { depth } \\
\text { (feet) }\end{array}$ & $\begin{array}{l}\text { Pier } \\
\text { scour } \\
\text { depth } \\
\text { (feet) }\end{array}$ & $\begin{array}{l}\text { Depth of } \\
\text { total scour } \\
\text { (feet) }\end{array}$ & $\begin{array}{c}\text { Elevation of } \\
\text { scour }^{2} \\
\text { (feet) }\end{array}$ & $\begin{array}{c}\text { Remaining } \\
\text { footing/pile } \\
\text { depth } \\
\text { (feet) }\end{array}$ \\
\hline \multicolumn{12}{|c|}{100 -year discharge is 1,800 cubic-feet per second } \\
\hline Left abutment & 0.0 & 482.3 & 482.3 & 468.0 & 471.0 & 0.3 & 6.1 & -- & 6.4 & 464.6 & -3.4 \\
\hline Right abutment & 31.9 & 483.0 & 483.0 & 468.0 & 469.3 & 0.3 & 13.2 & -- & 13.5 & 455.8 & -12.2 \\
\hline
\end{tabular}

1.Measured along the face of the most constricting side of the bridge.

2.Arbitrary datum for this study.

Table 2. Remaining footing/pile depth at abutments for the 500-year discharge at structure SHRETH00060032 on Town Highway 6, crossing Sargent Brook, Shrewsbury, Vermont.

[VTAOT, Vermont Agency of Transportation; --, no data]

\begin{tabular}{|c|c|c|c|c|c|c|c|c|c|c|c|}
\hline Description & Station $^{1}$ & $\begin{array}{l}\text { VTAOT } \\
\text { minimum } \\
\text { bridge seat } \\
\text { elevation } \\
\text { (feet) }\end{array}$ & $\begin{array}{c}\text { Surveyed } \\
\text { minimum } \\
\text { low-chord } \\
\text { elevation }{ }^{2} \\
\text { (feet) }\end{array}$ & $\begin{array}{c}\text { Bottom of } \\
\text { footing/pile } \\
\text { elevation }{ }^{2} \\
\text { (feet) }\end{array}$ & $\begin{array}{c}\text { Channel } \\
\text { elevation at } \\
\text { abutment/ } \\
\text { pier }^{2} \\
\text { (feet) }\end{array}$ & $\begin{array}{l}\text { Contraction } \\
\text { scour depth } \\
\text { (feet) }\end{array}$ & $\begin{array}{c}\text { Abutment } \\
\text { scour } \\
\text { depth } \\
\text { (feet) }\end{array}$ & $\begin{array}{l}\text { Pier } \\
\text { scour } \\
\text { depth } \\
\text { (feet) }\end{array}$ & $\begin{array}{l}\text { Depth of } \\
\text { total scour } \\
\text { (feet) }\end{array}$ & $\begin{array}{c}\text { Elevation of } \\
\text { scour }^{2} \\
\text { (feet) }\end{array}$ & $\begin{array}{c}\text { Remaining } \\
\text { footing/pile } \\
\text { depth } \\
\text { (feet) }\end{array}$ \\
\hline \multicolumn{12}{|c|}{500 -year discharge is 2,750 cubic-feet per second } \\
\hline Left abutment & 0.0 & 482.3 & 482.3 & 468.0 & 471.0 & 1.0 & 7.8 & -- & 8.8 & 462.2 & -5.8 \\
\hline Right abutment & 31.9 & 483.0 & 483.0 & 468.0 & 469.3 & 1.0 & 17.5 & -- & 18.5 & 450.8 & -17.2 \\
\hline
\end{tabular}

1.Measured along the face of the most constricting side of the bridge.

2.Arbitrary datum for this study. 


\section{SELECTED REFERENCES}

Arcement, G.J., Jr., and Schneider, V.R., 1989, Guide for selecting Manning's roughness coefficients for natural channels and flood plains: U.S. Geological Survey Water-Supply Paper 2339, 38 p.

Barnes, H.H., Jr., 1967, Roughness characteristics of natural channels: U.S. Geological Survey Water-Supply Paper 1849,213 p.

Benson, M. A., 1962, Factors Influencing the Occurrence of Floods in a Humid Region of Diverse Terrain: U.S. Geological Survey WaterSupply Paper 1580-B, 64 p.

Brown, S.A. and Clyde, E.S., 1989, Design of riprap revetment: Federal Highway Administration Hydraulic Engineering Circular No. 11, Publication FHWA-IP-89-016, 156 p.

Federal Highway Administration, 1983, Runoff estimates for small watersheds and development of sound design: Federal Highway Administration Report FHWA-RD-77-158.

Federal Highway Administration, 1993, Stream Stability and Scour at Highway Bridges: Participant Workbook: Federal Highway Administration Report FHWA-HI-91-011.

Froehlich, D.C., 1989, Local scour at bridge abutments in Ports, M.A., ed., Hydraulic Engineering--Proceedings of the 1989 National Conference on Hydraulic Engineering: New York, American Society of Civil Engineers, p. 13-18.

Hayes, D.C.,1993, Site selection and collection of bridge-scour data in Delaware, Maryland, and Virginia: U.S. Geological Survey WaterResources Investigation Report 93-4017, 23 p.

Interagency Advisory Committee on Water Data, 1982, Guidelines for determining flood flow frequency: U.S. Geological Survey, Bulletin 17B of the Hydrology Subcommittee, 190 p.

Johnson, C.G. and Tasker, G.D.,1974, Progress report on flood magnitude and frequency of Vermont streams: U.S. Geological Survey OpenFile Report 74-130, 37 p.

Lagasse, P.F., Schall, J.D., Johnson, F., Richardson, E.V., Chang, F., 1995, Stream Stability at Highway Structures: Federal Highway Administration Hydraulic Engineering Circular No. 20, Publication FHWA-IP-90-014, 144 p.

Laursen, E.M., 1960, Scour at bridge crossings: Journal of the Hydraulics Division, American Society of Civil Engineers, v. 86, no. HY2, p. 39-53.

Potter, W. D., 1957a, Peak rates of runoff in the Adirondack, White Mountains, and Maine woods area, Bureau of Public Roads

Potter, W. D., 1957b, Peak rates of runoff in the New England Hill and Lowland area, Bureau of Public Roads

Richardson, E.V. and Davis, S.R., 1995, Evaluating scour at bridges: Federal Highway Administration Hydraulic Engineering Circular No. 18, Publication FHWA-IP-90-017, 204 p.

Richardson, E.V., Simons, D.B., and Julien, P.Y., 1990, Highways in the river environment: Federal Highway Administration Publication FHWA-HI-90-016.

Ritter, D.F., 1984, Process Geomorphology: W.C. Brown Co., Debuque, Iowa, 603 p.

Shearman, J.O., 1990, User's manual for WSPRO--a computer model for water surface profile computations: Federal Highway Administration Publication FHWA-IP-89-027, 187 p.

Shearman, J.O., Kirby, W.H., Schneider, V.R., and Flippo, H.N., 1986, Bridge waterways analysis model; research report: Federal Highway Administration Publication FHWA-RD-86-108, 112 p.

Talbot, A.N., 1887, The determination of water-way for bridges and culverts.

U.S. Geological Survey, 1961, Killington Peak, Vermont 7.5 Minute Series quadrangle map: U.S. Geological Survey Topographic Maps, Photoinspected 1983, Scale 1:24,000. 


\section{APPENDIX A: \\ WSPRO INPUT FILE}




\section{WSPRO INPUT FILE}

Q

SK

XS

GR

GR

GR

GR

GR

$\mathrm{N}$

SA

*

$\mathrm{XS}$

GR

GR

GR

GR

GR

SA

XS

*

BR

GR

GR

GR

GR

*

CD

$\mathrm{N}$

$\mathrm{XR}$

GR

GR

GR

AS

GR

GR

GR

GR

GR

GR

*

$\mathrm{N}$

SA

HP 1 BRIDG

HP 2 BRIDG

$\mathrm{HP} 1$ APPR 1

FULLV

BRIDG

RDWAY

APPR1
U.S. Geological Survey WSPRO Input File shre032.wsp Hydraulic analysis for structure SHRETH00060032 Date: 10-MAR-98 TH 6 CROSSING SARGENT BROOK IN SHREWSBURY, VT RLB

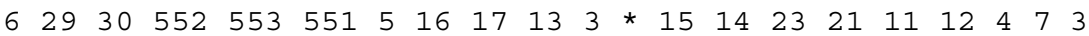

$1800.0 \quad 2750.0$

$0.0380 \quad 0.0380$

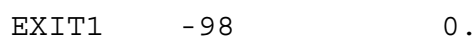

0.080

0.065

0.0

EXITX $-35 \quad 0$.

$$
-472.4,502.25
$$

$-54.8,474.64$

$35.0,469.87$

$57.2,470.24$

$-380.8,491.31$

$0.0,473.22$

$-242.4,481.26$

$18.3,469.90$

$40.7,469.52$

$47.0,469.14$

$62.4,473.93$

$71.6,475.91$

$107.2,494.59$

0.080

$$
0.0
$$

0.065

$0 * * *$

0.0019

SRD LSEL

XSSKEW

$\begin{array}{lll}0 & 482.68 & 0.0\end{array}$

$0.0,482.32$

$13.7,470.30$

$28.0,469.74$

$0.1,474.30$

$17.7,469.25$

$8.5,471.00$

$31.8,469.74$

$24.8,469.76$

$31.9,470.25$

$27.9,469.29$

$31.9,483.03$
$-101.7,479.61$

$28.8,469.68$

$52.1,469.06$

$84.4,478.04$

$0.0,482.32$

$\begin{array}{crrr}\text { BRTYPE } & \text { BRWDTH } & \text { WWANGL } & \text { WWWID } \\ 1 & 31.5 * * & 46.0 & 8.3\end{array}$

0.050

$\begin{array}{rrc}\text { SRD } & \text { EMBWID } & \text { IPAVE } \\ 12 & 20.1 & 2\end{array}$

$-542.7,507.95-345.8,489.51$

$-118.4,482.91$

$-42.2,484.32$

$-250.9,484.57$

$-176.2,482.90$

$89.7,487.02$

$138.1,489.89$

$0.0,485.21$

$33.0,485.79$

56

$-473.1,502.48$

$-161.3,481.57$

$0.0,475.54$

$22.4,471.72$

$43.4,474.56$

$83.1,483.11$

0.080

$-26.6$
0 .

$-405.3,494.48$

$-69.0,481.89$

$4.5,473.76$

$26.8,471.24$

$47.4,476.30$

$115.9,503.42$

0.060

475.241475 .24

475.24 * * 1800

478.311478 .31 


\section{APPENDIX B: \\ WSPRO OUTPUT FILE}


WSPRO OUTPUT FILE

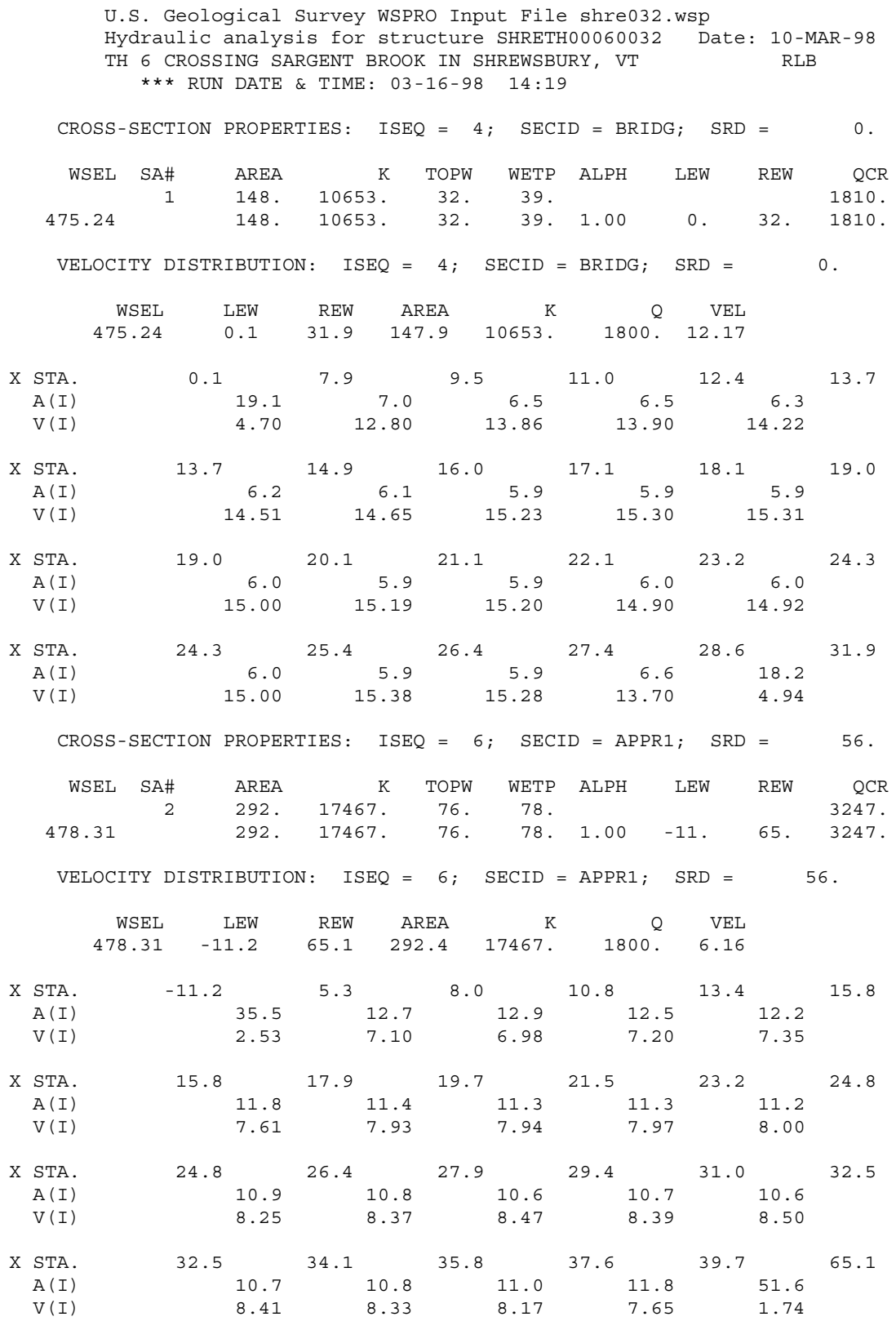


WSPRO OUTPUT FILE (continued)

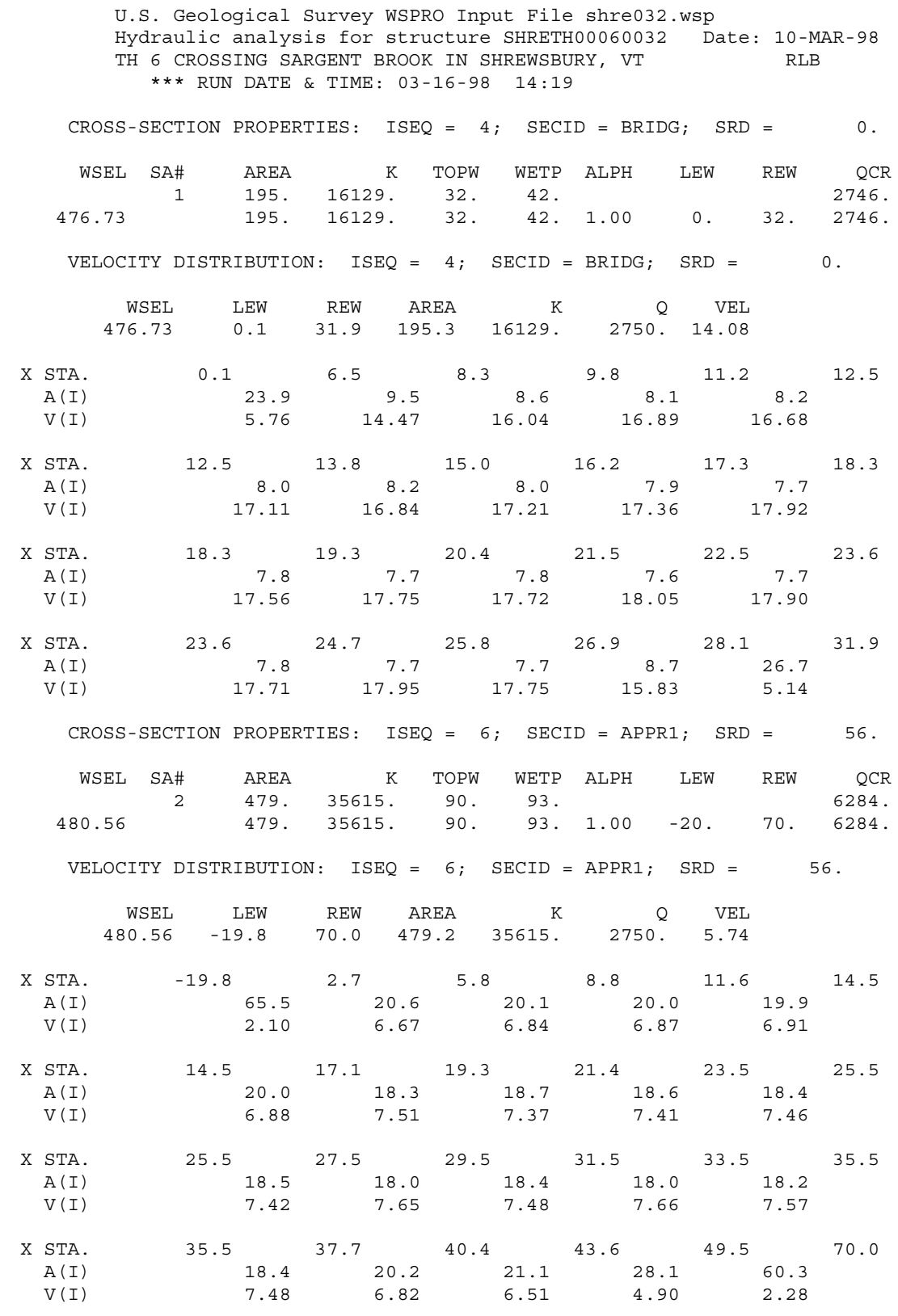




\section{WSPRO OUTPUT FILE (continued)}

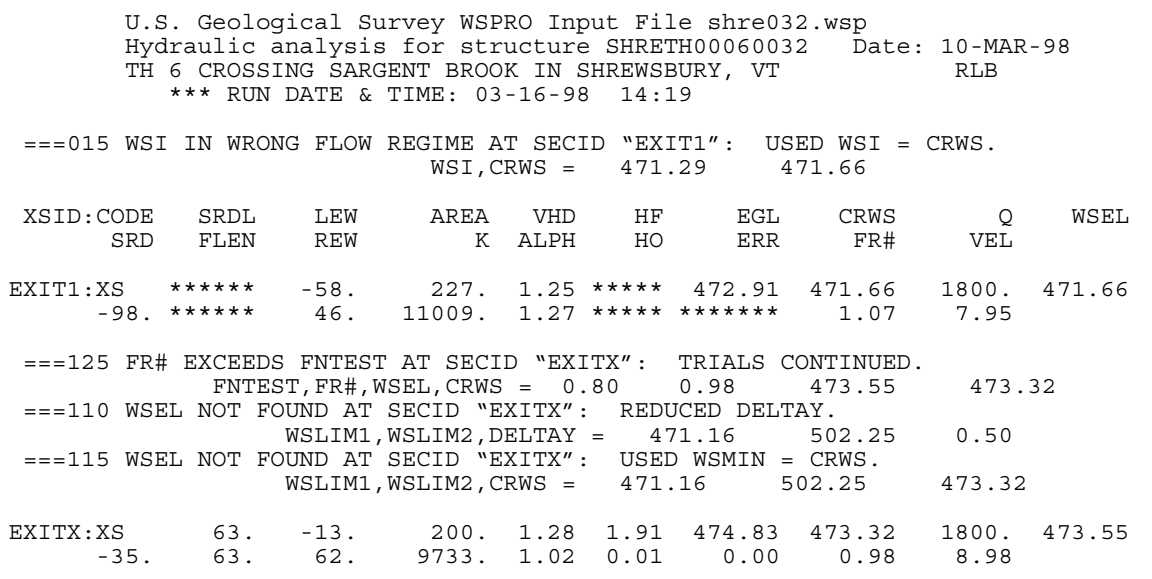

$==135$ CONVEYANCE RATIO OUTSIDE OF RECOMMENDED LIMITS.

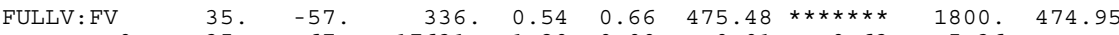

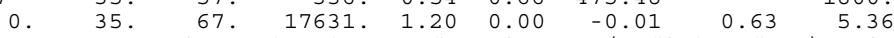
$<<<<$ THE ABOVE RESULTS REFLECT "NORMAL" (UNCONSTRICTED) FLOW $\gg>>>$

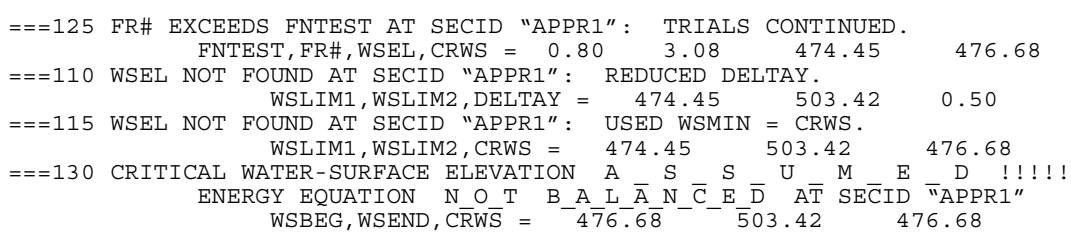




\section{WSPRO OUTPUT FILE (continued)}

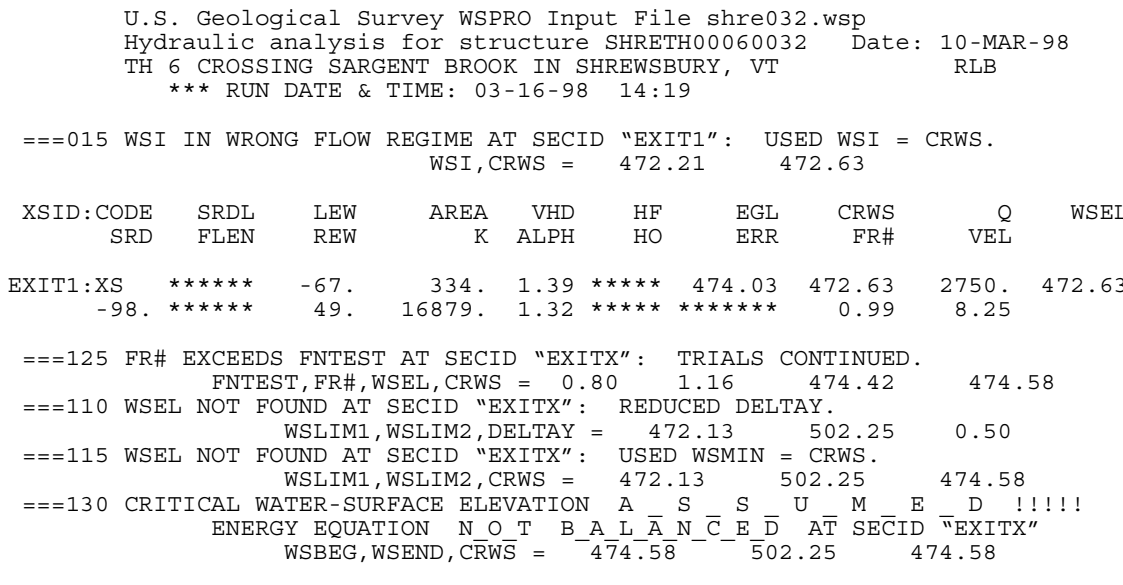




\section{APPENDIX C:}

\section{BED-MATERIAL PARTICLE-SIZE DISTRIBUTION}




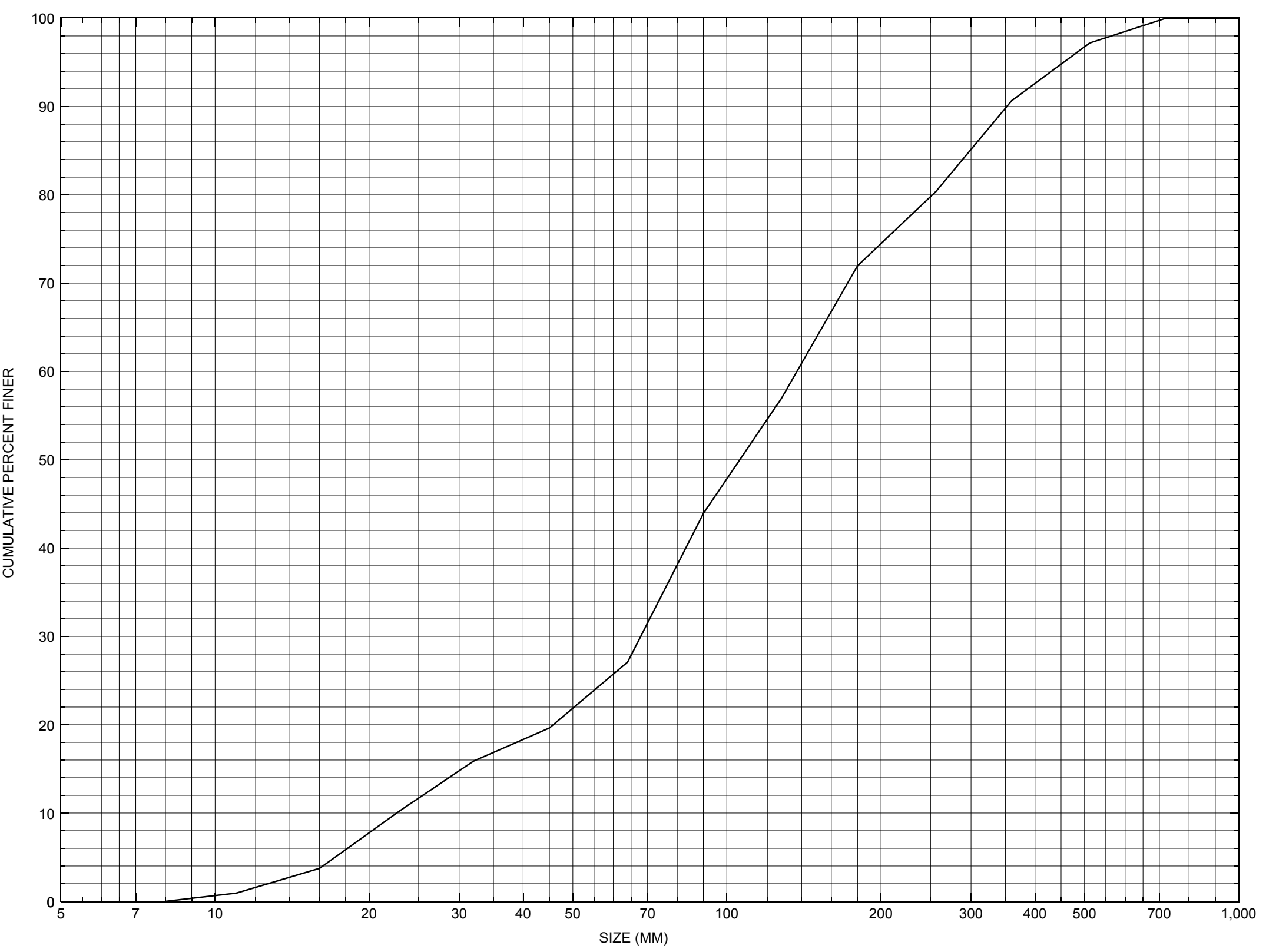

Appendix C. Bed material particle-size distribution for a pebble count in the channel approach of structure SHRETH00060032, in Shrewsbury, Vermont. 


\section{APPENDIX D: \\ HISTORICAL DATA FORM}




\section{Structure Number SHRETH00060032}

\section{General Location Descriptive}

Data collected by (First Initial, Full last name) $\mathbf{E}$. BOEHMLER

Date $(M M / D D / Y Y) \_\mathbf{0 3} / \underline{15} / \underline{95}$

Highway District Number (I - 2; nn) $\mathbf{0 3}$

Town (FIPS place code; I - 4; nnnnn) $\mathbf{6 5 2 7 5}$

Waterway (I - 6) BRANCH OF COLD RIVER

Route Number TH006

Topographic Map Killington Peak

Latitude (I - 16; nnnn.n) $\mathbf{4 3 3 2 9}$
County (FIPS county code; I - 3; nnn)

Mile marker (I - 11; nnn.nnn) $\mathbf{0 0 0 0 0 0}$

Road Name (I - 7): -

Vicinity (I - 9) 0.3 MI TO JCT CL 3 TH 12

Hydrologic Unit Code: $\underline{\mathbf{0 2 0 1 0 0 0 2}}$

Longitude (i - 17; nnnnn.n) $\mathbf{7 2 5 1 5}$

\section{Select Federal Inventory Codes}

FHWA Structure Number (I - 8) $\mathbf{1 0 1 1 2 2 0 0 3 2 1 1 2 2}$

Maintenance responsibility $(I-21 ; n n) \quad \mathbf{0 3}$

Year built (I - 27; YYYY) 1974

Average daily traffic, ADT (I - 29; nnnnnn) 000150

Year of ADT (I - 30; YY) $\mathbf{9 2}$

Opening skew to Roadway $(I-34 ; n n) \quad \mathbf{0 0}$

Operational status $(I-41 ; X)$ A

Structure type (I - 43; nnn) $\mathbf{3 0 2}$

Approach span structure type $(I-44 ; n n n) \quad \mathbf{0 0 0}$

Number of spans (I - 45; nnn) $\mathbf{0 0 1}$

Number of approach spans (I - 46; nnnn) $\mathbf{0 0 0 0}$

Comments:

The structural inspection report of 6/7/94 indicates the structure is a steel stringer type bridge with a concrete deck. The abutments have randomly located cracks in the concrete. The wingwall concrete has random cracks and some spalling. The footing on the right abutment is exposed and the footing concrete has areas of heavy scaling and some minor local scour. The channel bed consists primarily of boulders and gravel. There is heavy stone riprap noted at both upstream wingwalls. There are a few small trees and other debris in the channel downstream of the bridge. No undermining or settling is reported. There is very little information readily available in the hydraulic section file. 


\section{Bridge Hydrologic Data}

Is there hydrologic data available? $\underline{\mathbf{Y}}$ if No, type ctrl- $n$ h VTAOT Drainage area $\left(\mathrm{mi}^{2}\right): \underline{\mathbf{6 . 4}}$

Terrain character:

Stream character \& type: -

Streambed material: Gravel and boulders

Discharge Data (cfs): $\quad \mathrm{Q}_{2.33}-$

$\mathrm{Q}_{50} \mathbf{1 4 5 0}$

$\mathrm{Q}_{10} \frac{\mathbf{8 5 0}}{\mathrm{Q}_{100}-}$

$\mathrm{Q}_{25}$

$Q_{500}$

Record flood date $(M M / D D / Y Y)$ :

Water surface elevation (ft): -

Estimated Discharge (cfs): Velocity at $\mathrm{Q} \underline{\mathbf{2 5}}$ $(f t / s):$ 13.0

Ice conditions (Heavy, Moderate, Light) : Debris (Heavy, Moderate, Light):

The stage increases to maximum highwater elevation (Rapidly, Not rapidly):

The stream response is (Flashy, Not flashy):

Describe any significant site conditions upstream or downstream that may influence the stream's stage: -

Watershed storage area (in percent):

The watershed storage area is: - (1-mainly at the headwaters; 2- uniformly distributed; 3-immediatly upstream oi the site)

Water Surface Elevation Estimates for Existing Structure:

\begin{tabular}{|l|l|l|l|l|l|}
\hline Peak discharge frequency & $Q_{2.33}$ & $Q_{10}$ & $Q_{25}$ & $Q_{50}$ & $Q_{100}$ \\
Water surface elevation (ft) $)$ & - & - & $\mathbf{5 . 4}$ & $\mathbf{6 . 4}$ & - \\
Velocity $(\mathrm{ft} / \mathrm{sec})$ & - & - & $\mathbf{1 3 . 0}$ & - & - \\
\hline
\end{tabular}

Long term stream bed changes: -

Is the roadway overtopped below the $\mathrm{Q}_{100}$ ? (Yes, No, Unknown): $\mathbf{U} \quad$ Frequency: Relief Elevation $(f t)$ : Discharge over roadway at $Q_{100}\left(f^{3} / \mathrm{sec}\right)$ :

Are there other structures nearby? (Yes, No, Unknown): Upstream distance (miles): Town: If No or Unknown, type ctrl-n os Highway No. : Structure No. : Year Built:

Clear span (ft): Clear Height (ft): Full Waterway $\left(f t^{2}\right)$ : 
Downstream distance (miles): Town: Year Built:

Highway No. : Structure No. : Structure Type:

Clear span (ft): Clear Height $(f t)$ : Full Waterway $\left(f^{2}\right)$ : -

Comments:

\section{USGS Watershed Data}

Watershed Hydrographic Data

Drainage area $(D A)$

Watershed storage (ST) $\mathrm{mi}^{2}$ Lake/pond/swamp area 0 $\mathrm{mi}^{2}$

Bridge site elevation $1610 \quad \mathrm{ft}$ $\%$

Main channel length 4.52 mi $10 \%$ channel length elevation $\mathbf{1 7 0 0}$ $\mathrm{ft} \quad 85 \%$ channel length elevation 2900 $\mathrm{ft}$ Main channel slope $(S) \quad \mathbf{3 5 4 . 2 1} \mathrm{ft} / \mathrm{mi}$

Watershed Precipitation Data

Average site precipitation in Average headwater precipitation in

Maximum 2yr-24hr precipitation event $(124,2)$ in

Average seasonal snowfall (Sn) $\mathrm{ft}$ 


\section{Bridge Plan Data}

Are plans available? $\mathbf{Y}$ If no, type ctrl-n pl

Date issued for construction (MM/YYYY): $11 / 1973$ Project Number DSR 3C S5

Minimum channel bed elevation: 472.0

Low superstructure elevation: USLAB $\mathbf{4 8 2 . 3 2}$ DSLAB $\mathbf{4 8 2 . 3 2}$ USRAB 483.0 DSRAB 483.0 Benchmark location description:

BM\#1 is a spike in the trunk or root of a 12 inch diameter spruce tree, located 223 feet right bankward on the roadway from the right abutment and 15 feet from the centerline of the roadway downstream, elevation 500.00.

Reference Point (MSL, Arbitrary, Other): Arbitrary $\quad$ Datum (NAD27, NAD83, Other): Arbitrary Foundation Type: 1 (1-Spreadfooting; 2-Pile; 3- Gravity; 4-Unknown)

If 1: Footing Thickness $\mathbf{2 . 0} \quad$ Footing bottom elevation: $\underline{\mathbf{4 6 8 . 0}}$

If 2: Pile Type: ___ (1-Wood; 2-Steel or metal; 3-Concrete) Approximate pile driven length: -

If 3: Footing bottom elevation: -

Is boring information available? $\underline{\mathbf{Y}}$ If no, type ctrl-n bi Number of borings taken: 1

Foundation Material Type: 1 (1-regolith, 2-bedrock, 3-unknown)

Briefly describe material at foundation bottom elevation or around piles:

The footings are shown as probably set in a very dense sandy silt and gravel.

Comments:

The same hydraulic information in the hydraulics section folder is found printed on the plans. The actual channel bed elevation prior to installing the bridge is shown on the plans at least 2 feet higher than the top of each abutment footing. The low superstructure elevation given is actually the minimum value. Some other points with elevations are: 1 ) The point on the top bankward edge of the upstream left wingwall where the concrete slope changes from horizontal to downward, elevation 485.04 , and 2 ) the point at the same location as in (1) but on the upstream right wingwall, elevation 485.76. 


\section{Cross-sectional Data}

Is cross-sectional data available? $\underline{\mathbf{Y}}$ If no, type ctrl-n xs

Source (FEMA, VTAOT, Other)? VTAOT

Comments: Upstream bridge face channel cross section from left to right banks.

\begin{tabular}{|l|l|l|l|l|l|l|l|l|l|l|l|}
\hline Station & $\mathbf{0 . 7}$ & $\mathbf{5 . 0}$ & $\mathbf{1 0 . 0}$ & $\mathbf{1 1 . 0}$ & $\mathbf{2 0 . 0}$ & $\mathbf{3 0 . 5}$ & $\mathbf{3 0 . 5}$ & $\mathbf{3 0 . 5}$ & - & - & - \\
\hline Feature & LCL & - & - & LEW & - & TD & REW & LCR & - & - & - \\
\hline $\begin{array}{l}\text { Low chord } \\
\text { elevation }\end{array}$ & 482.3 & - & - & - & - & - & - & 483.0 & - & - & - \\
\hline $\begin{array}{l}\text { Bed } \\
\text { elevation }\end{array}$ & 473.1 & 473.0 & 472.7 & 472.5 & 472.2 & 471.8 & 472.5 & 471.8 & - & - & - \\
\hline $\begin{array}{l}\text { Low chord } \\
\text { to bed }\end{array}$ & 9.2 & - & - & - & - & - & - & 12.2 & - & - & - \\
\hline Station & - & - & - & - & - & - & - & - & - & - & - \\
\hline Feature & - & - & - & - & - & - & - & - & - & - & - \\
\hline $\begin{array}{l}\text { Low chord } \\
\text { elevation }\end{array}$ & - & - & - & - & - & - & - & - & - & - & - \\
\hline $\begin{array}{l}\text { Bed } \\
\text { elevation }\end{array}$ & - & - & - & - & - & - & - & - & - & - & - \\
\hline $\begin{array}{l}\text { Low chord } \\
\text { to bed }\end{array}$ & - & - & - & - & - & - & - & - & - & - & - \\
\hline
\end{tabular}

Source (FEMA, VTAOT, Other)? VTAOT

Comments: Downstream bridge face channel cross section from left to right banks.

\begin{tabular}{|l|l|l|l|l|l|l|l|l|l|l|l|}
\hline Station & $\mathbf{0 . 5}$ & $\mathbf{1 0 . 0}$ & $\mathbf{1 5 . 0}$ & $\mathbf{1 9 . 0}$ & $\mathbf{3 0 . 3}$ & $\mathbf{3 0 . 3}$ & $\mathbf{3 0 . 3}$ & - & - & - & - \\
\hline Feature & LCL & LEW & - & - & TD & REW & LCR & - & - & - & - \\
\hline $\begin{array}{l}\text { Low chord } \\
\text { elevation }\end{array}$ & 482.3 & - & - & - & - & - & 483.0 & - & - & - & - \\
\hline $\begin{array}{l}\text { Bed } \\
\text { elevation }\end{array}$ & 473.5 & 473.2 & 473.0 & 472.8 & 472.3 & 473.3 & 472.3 & - & - & - & - \\
\hline $\begin{array}{l}\text { Low chord } \\
\text { to bed }\end{array}$ & 8.8 & - & - & - & - & - & 10.7 & - & - & - & - \\
\hline Station & - & - & - & - & - & - & - & - & - & - & - \\
\hline Feature & - & - & - & - & - & - & - & - & - & - & - \\
\hline $\begin{array}{l}\text { Low chord } \\
\text { elevation }\end{array}$ & - & - & - & - & - & - & - & - & - & - & - \\
\hline $\begin{array}{l}\text { Bed } \\
\text { elevation }\end{array}$ & - & - & - & - & - & - & - & - & - & - & - \\
\hline $\begin{array}{l}\text { Low chord } \\
\text { to bed }\end{array}$ & - & - & - & - & - & - & - & - & - & - & - \\
\hline
\end{tabular}




\section{APPENDIX E: \\ LEVEL I DATA FORM}


U. S. Geological Survey

Bridge Field Data Collection and Processing Form

Qa/Qc Check by: JD Date: $\mathbf{5 / 1 6 / 9 7}$

\section{Structure Number}

SHRETH00060032

Computerized by: JD Date: $\mathbf{5 / 1 6 / 9 7}$

Reviewd by: $\quad$ RB Date: $\underline{\mathbf{3} / \mathbf{1 8} / \mathbf{9 8}}$

\section{A. General Location Descriptive}

1. Data collected by (First Initial, Full last name) $\underline{\mathbf{E}}$. Boehmler

Date $(M M / D D / Y Y)$

09

$28 / 1995$

2. Highway District Number $\mathbf{3}$

Mile marker $\mathbf{0}$

County Rutland (021)

Town Shrewsbury (65275)

Waterway $(I-6)$ Branch of Cold River (Sargent Brook)

Route Number TH6

Road Name -

3. Descriptive comments:

Hydrologic Unit Code: $\mathbf{0 2 0 1 0 0 0 2}$

This structure is located 0.3 mile from town highway 12.

\section{B. Bridge Deck Observations}
4. Surface cover... LBUS 6
RBUS 6
LBDS 6
RBDS 6
Overall 6

(2b us,ds,lb,rb: 1- Urban; 2- Suburban; 3- Row crops; 4- Pasture; 5- Shrub- and brushland; 6- Forest; 7- Wetland)
5. Ambient water surface... US 2
UB 1
DS 1
(1- pool; 2- riffle)

6. Bridge structure type 1 (1- single span; 2- multiple span; 3- single arch; 4- multiple arch; 5- cylindrical culvert; 6- box culvert; or 7- other)
7. Bridge length $\mathbf{3 6 . 0}$
(feet)
Span length $\underline{\mathbf{3 3 . 0}}$
(feet)
Bridge width 20.1 (feet)

\section{Road approach to bridge:}
8. LB 1
RB 2
( 0 even, 1- lower, 2- higher)
9. LB_2
RB $\underline{2}$
(1- Paved, 2- Not paved)

10. Embankment slope (run / rise in feet / foot)

US left

US right

\begin{tabular}{|c|c|c|c|}
\hline \multicolumn{2}{|c|}{ Protection } & \multirow{2}{*}{ 13.Erosion } & 14.Severity \\
\hline 11.Type & 12.Cond. & $\underline{\mathbf{2}}$ & $\underline{\mathbf{2}}$ \\
\hline $\mathbf{0}$ & - & $\underline{\mathbf{2}}$ & $\underline{\mathbf{1}}$ \\
\hline $\mathbf{0}$ & - & $\underline{\mathbf{0}}$ & $\mathbf{0}$ \\
\hline $\mathbf{0}$ & - & $\mathbf{2}$ & $\mathbf{1}$ \\
\hline $\mathbf{0}$ & - & $\underline{\mathbf{2}}$ & $\mathbf{-}$ \\
\hline
\end{tabular}

Bank protection types: 0- none; 1- < 12 inches;

2- < 36 inches; 3- < 48 inches;

4- < 60 inches; 5- wall / artificial levee

Bank protection conditions: 1- good; 2- slumped;

3- eroded; 4- failed

Erosion: 0 - none; 1- channel erosion; 2 -

road wash; 3- both; 4- other

Erosion Severity: 0 - none; 1- slight; 2- moderate; 3- severe

\section{Channel approach to bridge (BF):}

15. Angle of approach: $\mathbf{3 0}$

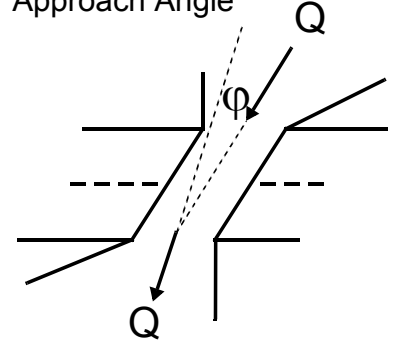

17. Channel impact zone 1:

Where? RB (LB, RB)

Range? 30 feet US

Channel impact zone 2:

Where? _ _ $(L B, R B)$

Range? - $\quad$ feet (US, UB, DS) to feet -

Impact Severity: 0- none to very slight; 1- Slight; 2- Moderate; 3- Severe
16. Bridge skew: $\mathbf{0}$ Bridge Skew Angle

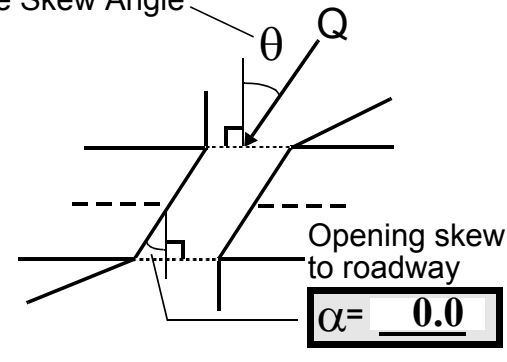

\section{Exist? $\mathbf{Y}(Y$ or $N)$}

Severity 2

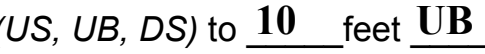

Exist? $\mathbf{N}(Y$ or $N)$

Severity -

to roadway

.0


18. Bridge Type: 4

1a- Vertical abutments with wingwalls

$1 \mathrm{~b}$ - Vertical abutments without wingwalls

2- Vertical abutments and wingwalls, sloping embankment Wingwalls parallel to abut. face

3- Spill through abutments

4- Sloping embankment, vertical wingwalls and abutments

Wingwall angle less than $90^{\circ}$.

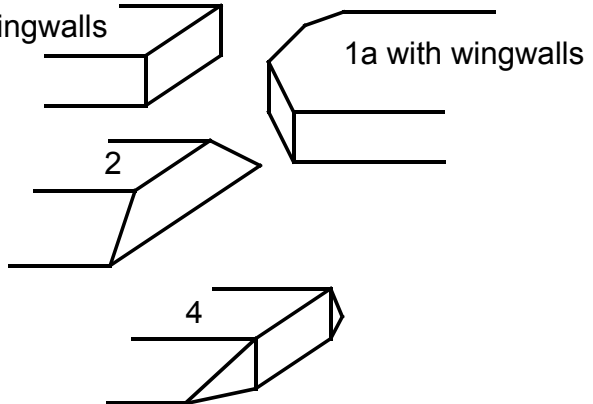

19. Bridge Deck Comments (surface cover variations, measured bridge and span lengths, bridge type variations, approach overflow width, etc.)

4. The surface cover is forest except for a pasture two bridge lengths bankward on the downstream right bank.

5. The upstream water surface is riffled and slopes consistently from 250 feet upstream to 50 feet upstream where the channel steepens until 2 feet under the bridge. The channel slope flattens out and the current water surface is pooled from 2 feet under the bridge to 30 feet downstream where the channel slope steepens again.

7. The measured bridge dimensions were the same as the historical values.

\section{Upstream Channel Assessment}

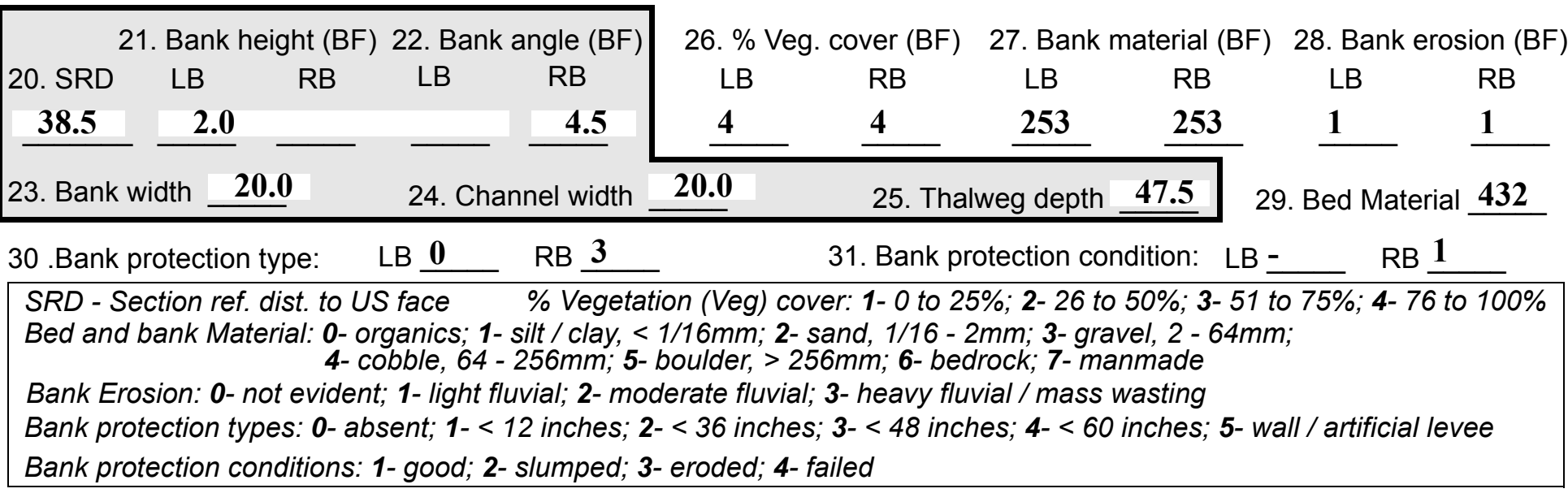

32. Comments (bank material variation, minor inflows, protection extent, etc.):

27. The banks are low, with predominantly sand and boulder material.

The channel is straight until 30 feet upstream of the bridge where it takes a bend to the left.

30. The right bank protection extends from 25 feet upstream to 0 feet upstream. It is also wingwall protection. 
33.Point/Side bar present? $\mathbf{Y}$

$(Y$ or $N$. if $N$ type ctrl-n pb)34. Mid-bar distance: 0US

35. Mid-bar width: 15

36. Point bar extent: $\mathbf{5 0}$ feet US

(US, UB) to 40 feet $\underline{\text { DS }}$ (US, UB, DS) positioned $\mathbf{0}$ \%LB to $\mathbf{5 0}$ $\% R B$

37. Material: $\mathbf{3 2 4}$

38. Point or side bar comments (Circle Point or Side; Note additional bars, material variation, status, etc.):

The upstream portion of this bar is vegetated with grass and shrubs, growing in silt, clay, and sand material.

39. Is a cut-bank present? $\mathbf{N}$ ( $Y$ or if $N$ type ctrl-n $c b)$

40. Where? (LB or RB)

41. Mid-bank distance: -

42. Cut bank extent: feet (US, UB) to feet (US, UB, DS)

43. Bank damage: (1- eroded and/or creep; 2- slip failure; 3- block failure)

44. Cut bank comments (eg. additional cut banks, protection condition, etc.):

There is a cut-bank on the left bank around 250 feet upstream, on the outside of a sharp bend.

45. Is channel scour present? $\mathbf{N}$ ( $Y$ or if $N$ type ctrl-n cs)

47. Scour dimensions: Length Width Depth : 46. Mid-scour distance: -

48. Scour comments (eg. additional scour areas, local scouring process, etc.):

NO CHANNEL SCOUR

49. Are there major confluences? $\mathbf{N}$

51. Confluence 1: Distance Confluence 2: Distance 52. Enters on Enters on 54. Confluence comments (eg. confluence name):

NO MAJOR CONFLUENCES
50. How many? -

53. Type(1- perennial; 2- ephemeral)

Type (1-perennial; 2- ephemeral) ( $L B$ or $R B)$ (LB or $R B)$

\section{Under Bridge Channel Assessment}

55. Channel restraint (BF)? LB 2

\begin{tabular}{|ccccc}
\hline \multicolumn{3}{|c}{ 56. Height (BF) } & \multicolumn{3}{c}{57 Angle (BF) } \\
LB & RB & LB & RB \\
32.0 & & & $\mathbf{1 . 0}$ & \\
\hline
\end{tabular}
(1- natural bank; 2- abutment; 3- artificial levee)

58. Bank width (BF) -

59. Channel width \begin{tabular}{lclc}
\multicolumn{2}{l}{ 61. Material (BF) } & \multicolumn{3}{l}{ 62. Erosion (BF) } \\
LB & RB & LB & RB \\
$\mathbf{2}$ & $\mathbf{7}$ & & $\mathbf{7}$ \\
\hline
\end{tabular}

Bed and bank Material: 0- organics; 1- silt / clay, < 1/16mm; 2- sand, 1/16 - 2mm; 3- gravel, 2 - 64mm; 4- cobble, 64 - 256mm; 5- boulder, > 256mm; 6- bedrock; 7- manmade

Bank Erosion: 0- not evident; 1- light fluvial; 2- moderate fluvial; 3- heavy fluvial / mass wasting

64. Comments (bank material variation, minor inflows, protection extent, etc.):

432 
65. Debris and Ice Is there debris accumulation?

$(Y$ or $N)$ 66. Where? $\mathbf{N}$

(1- Upstream; 2- At bridge; 3- Both)

67. Debris Potential ( 1- Low; 2- Moderate; 3- High)

68. Capture Efficiency 2

(1-Low; 2- Moderate; 3- High)

69. Is there evidence of ice build-up? 2

Ice Blockage Potential $\mathbf{N}$

(1- Low; 2- Moderate; 3- High)

70. Debris and Ice Comments:

2

Some debris is scattered in the channel downstream of the structure, but it has not accumulated in one particular place. The banks in the study area are heavily wooded. The bend and the point bar just upstream of the bridge could contribute to the capturing of ice and debris.

\begin{tabular}{|l|c|c|c|c|c|c|c|c|}
\hline Abutments & $\begin{array}{c}\text { 71. Attack } \\
\angle \text { (BF) }\end{array}$ & $\begin{array}{c}\text { 72. Slope } \angle \\
\text { (Qmax) }\end{array}$ & $\begin{array}{c}\text { 73. Toe } \\
\text { loc. (BF) }\end{array}$ & $\begin{array}{c}\text { 74. Scour } \\
\text { Condition }\end{array}$ & $\begin{array}{c}75 . \text { Scour } \\
\text { depth }\end{array}$ & $\begin{array}{c}\text { 76. Exposure } \\
\text { depth }\end{array}$ & 77. Material & 78. Length \\
\hline LABUT & & $\mathbf{0}$ & $\mathbf{9 0}$ & $\mathbf{2}$ & $\mathbf{0}$ & $\mathbf{0}$ & $\mathbf{0}$ & $\mathbf{9 0 . 0}$ \\
\hline RABUT & $\mathbf{1}$ & $\mathbf{1 0}$ & $\mathbf{9 0}$ & & & $\mathbf{2}$ & $\mathbf{2}$ & $\mathbf{3 2 . 0}$ \\
\hline
\end{tabular}

Pushed: $L B$ or RB

Toe Location (Loc.): 0- even, 1- set back, 2- protrudes

Scour cond.: 0- not evident; 1- evident (comment); 2- footing exposed; 3-undermined footing; 4- piling exposed; 5- settled; 6- failed

Materials: 1- Concrete; 2- Stone masonry or drywall; 3- steel or metal; 4- wood

79. Abutment comments (eg. undermined penetration, unusual scour processes, debris, etc.):

$\mathbf{0}$

0.5

1

76. The right abutment footing is exposed to a depth between 0 and $0.5 \mathrm{ft}$ along its entire length.

80. Wingwalls:

Exist? Material? Scour Scour Exposure $\begin{aligned} & 81 . \\ & \text { Angle? Length? }\end{aligned}$ Condition? depth? depth?

USLWW:

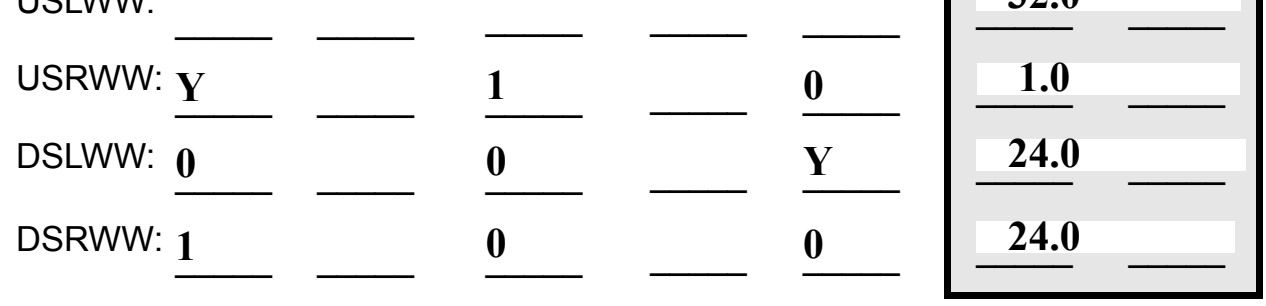

Wingwall materials: 1- Concrete; 2- Stone masonry or drywall; 3- steel or metal; 4- wood

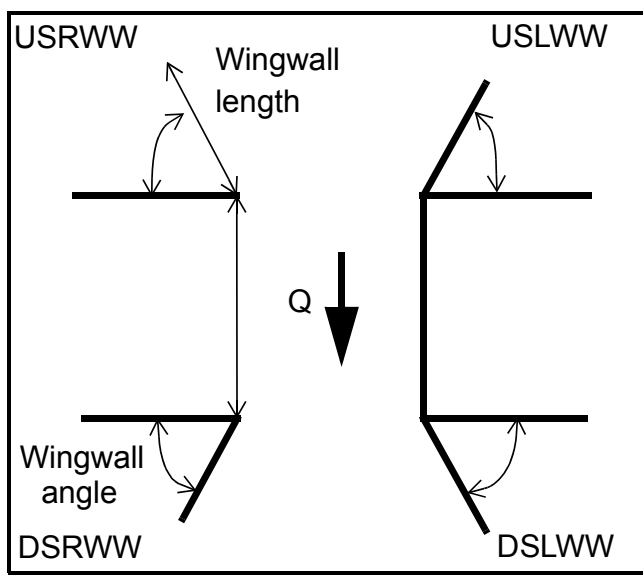

82. Bank / Bridge Protection:

\begin{tabular}{|l|l|l|l|l|l|l|l|l|}
\hline Location & USLWW & USRWW & LABUT & RABUT & LB & RB & DSLWW & DSRWW \\
\hline Type & $\mathbf{0}$ & $\mathbf{0}$ & $\mathbf{Y}$ & $\mathbf{0}$ & $\mathbf{1}$ & $\mathbf{1}$ & $\mathbf{1}$ & - \\
\hline Condition & $\mathbf{Y}$ & $\mathbf{0}$ & $\mathbf{1}$ & $\mathbf{0 . 5}$ & $\mathbf{1}$ & $\mathbf{1}$ & $\mathbf{1}$ & - \\
\hline Extent & $\mathbf{1}$ & $\mathbf{0}$ & $\mathbf{2}$ & $\mathbf{3}$ & $\mathbf{3}$ & $\mathbf{2}$ & $\mathbf{0}$ & - \\
\hline
\end{tabular}

Bank / Bridge protection types: 0- absent; 1- < 12 inches; 2- < 36 inches; 3- < 48 inches; 4- < 60 inches; 
83. Wingwall and protection comments (eg. undermined penetration, unusual scour processes, etc.):

-
-
-
-
-
2
1
1
2
1
3

Piers:

84. Are there piers? 80. (Y or if $N$ type ctrl-n pr)

\begin{tabular}{|l|l|l|l|l|l|l|l|}
\hline \multirow{2}{*}{$\begin{array}{l}85 . \\
\text { Pier no. }\end{array}$} & \multicolumn{3}{|c|}{ width (w) feet } & \multicolumn{5}{c|}{ elevation (e) feet } \\
\cline { 2 - 8 } & w1 & w2 & w3 & e@w1 & e@w2 & e@w3 \\
\hline Pier 1 & & & & $\mathbf{2 5 . 0}$ & $\mathbf{1 4 . 0}$ & $\mathbf{7 0 . 0}$ \\
\hline Pier 2 & & & & $\mathbf{1 0 . 0}$ & $\mathbf{4 5 . 0}$ & $\mathbf{1 2 . 0}$ \\
\hline Pier 3 & & & - & $\mathbf{5 0 . 0}$ & $\mathbf{1 7 . 0}$ & - \\
\hline Pier 4 & - & - & - & - & - & - \\
\hline
\end{tabular}

\begin{tabular}{|l|l|l|l|l|}
\hline Level 1 Pier Descr. & \multicolumn{1}{|c|}{1} & \multicolumn{1}{|c|}{2} & \multicolumn{1}{|c|}{3} & \multicolumn{1}{|c|}{4} \\
\hline 86. Location (BF) & The & een 0 & abut- & stone \\
\hline 87. Type & dow & and & ment & fill. \\
\hline 88. Material & nstre & $\mathbf{0 . 5}$ & to 6 & $\mathbf{8 2 .}$ \\
\hline 89. Shape & am & ft, & feet & The \\
\hline 90. Inclined? & right & from & dow & left \\
\hline 91. Attack $\angle$ (BF) & wing & the & nstre & abut \\
\hline 92. Pushed & wall & point & am & ment \\
\hline 93. Length (feet) & - & - & - & - \\
\hline 94. \# of piles & foot- & wher & wher & is \\
\hline 95. Cross-members & ingis & e it & e it is & pro- \\
\hline 96. Scour Condition & expo & meet & cov- & tecte \\
\hline 97. Scour depth & sed & s the & ered & d by \\
\hline 98. Exposure depth & betw & right & with & stone \\
\hline
\end{tabular}

LFP, LTB, LB, MCL, MCM, MCR, RB, RTB, RFP

1- Solid pier, 2- column, 3- bent

1-Wood; 2-concrete; 3- metal; 4- stone

1- Round; 2- Square; 3- Pointed

Y-yes; $N-$ no

$L B$ or $R B$

0- none; 1- laterals; 2- diagonals; 3- both

0- not evident; 1- evident (comment);

2- footing exposed; 3- piling exposed;

4- undermined footing; 5- settled; 6- failed 
99. Pier comments (eg. undermined penetration, protection and protection extent, unusual scour processes, etc.):

\section{fill and point bar material.}

$\mathbf{N}$

100.

\section{E. Downstream Channel Assessment}

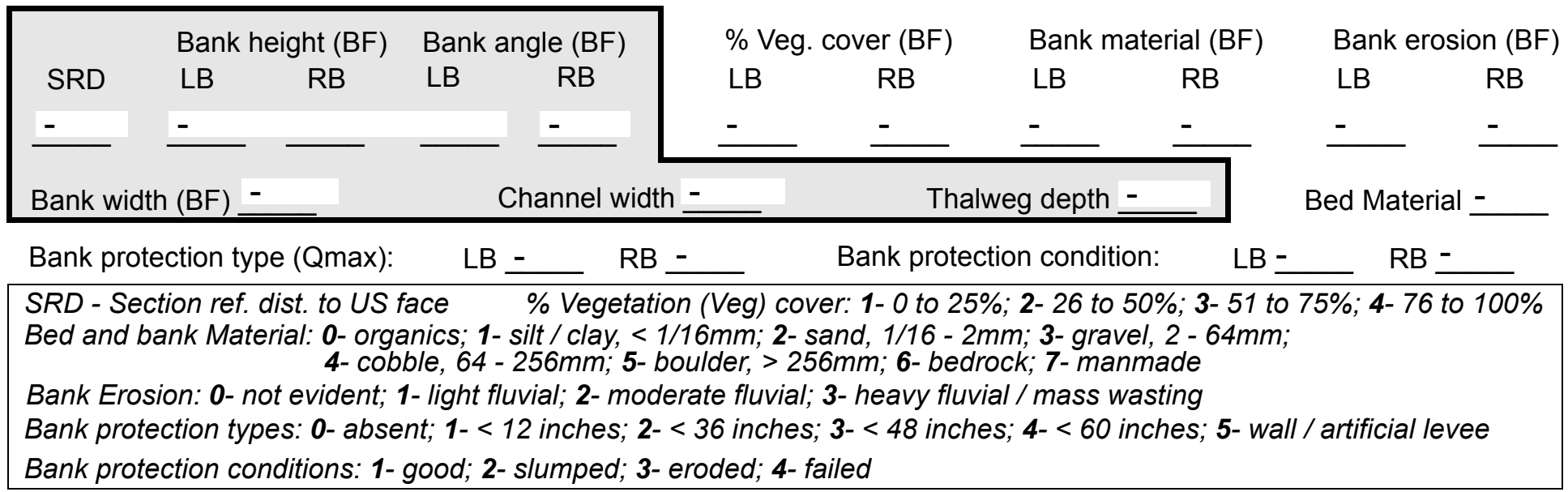

Comments (eg. bank material variation, minor inflows, protection extent, etc.):

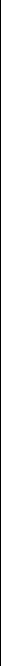

\section{Is a drop structure present? __ ( $Y$ or $N$, if $N$ type ctrl-n $d s) \quad$ 102. Distance: ___ feet}
103. Drop: - feet
104. Structure material: -
(1- steel sheet pile; 2- wood pile; 3- concrete; 4- other)

105. Drop structure comments (eg. downstream scour depth):

$-$

$-$

$-$

$-$ 
106. Point/Side bar present? (Y or $N$. if $N$ type ctrl-n pb)Mid-bar distance:

Mid-bar width: -

Point bar extent: feet -

(US, UB, DS) to feet (US, UB, DS) positioned \%LB to $\%$ RB Material:

Point or side bar comments (Circle Point or Side; note additional bars, material variation, status, etc.):

S a cut-bank present? $\mathbf{N}$ (Y or if $N$ type ctrl-n cb) Where? $\underline{\mathbf{O}}$ (LB or RB) Mid-bank distance: PIE Cut bank extent: $\underline{\mathbf{R S}}$ feet ___ (US, UB, DS) to feet __ (US, UB, DS)

Bank damage: (1- eroded and/or creep; 2- slip failure; 3- block failure)

Cut bank comments (eg. additional cut banks, protection condition, etc.):

Is channel scour present? Scour dimensions: Length $\underline{4}$ Width 253 Depth: 253

Scour comments (eg. additional scour areas, local scouring process, etc.): 435

0

$\mathbf{0}$

Are there major confluences? Confluence 1: Distance The Confluence 2: Distance right - $\quad$ (Y or if N type ctrl-n mc) Enters on left (LB or RB) Enters on ban (LB or RB) Confluence comments (eg. confluence name): are low banks and do not show signs of erosion.

\section{F. Geomorphic Channel Assessment}

107. Stage of reach evolution

1- Constructed

2- Stable

3- Aggraded

4- Degraded

5- Laterally unstable

6- Vertically and laterally unstable

Mid-scour distance: 4
How many? 100.

Type and (1-perennial; 2- ephemeral)

Type $\underline{\text { ks }}$ (1-perennial; 2- ephemeral)

Positioned 1 _ \%LB to 1 
108. Evolution comments (Channel evolution not considering bridge effects; See HEC-20, Figure 1 for geomorphic descriptors): 


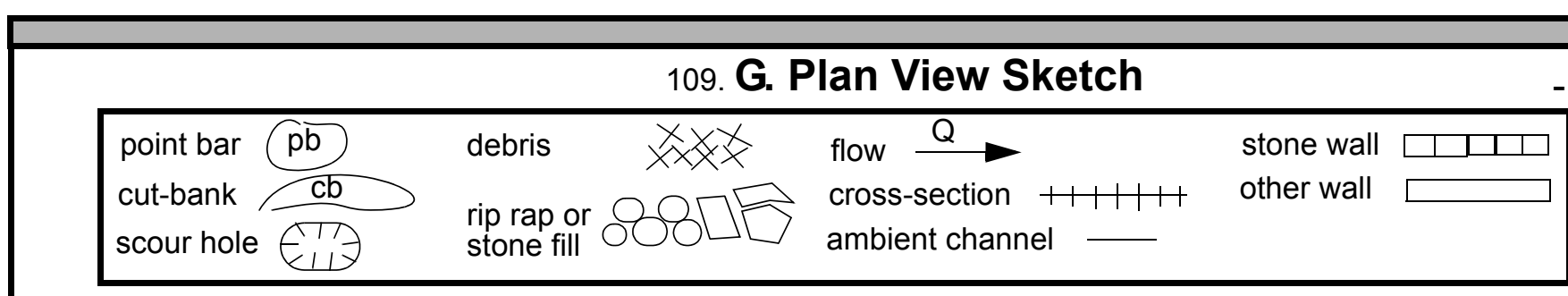


APPENDIX F:

SCOUR COMPUTATIONS 


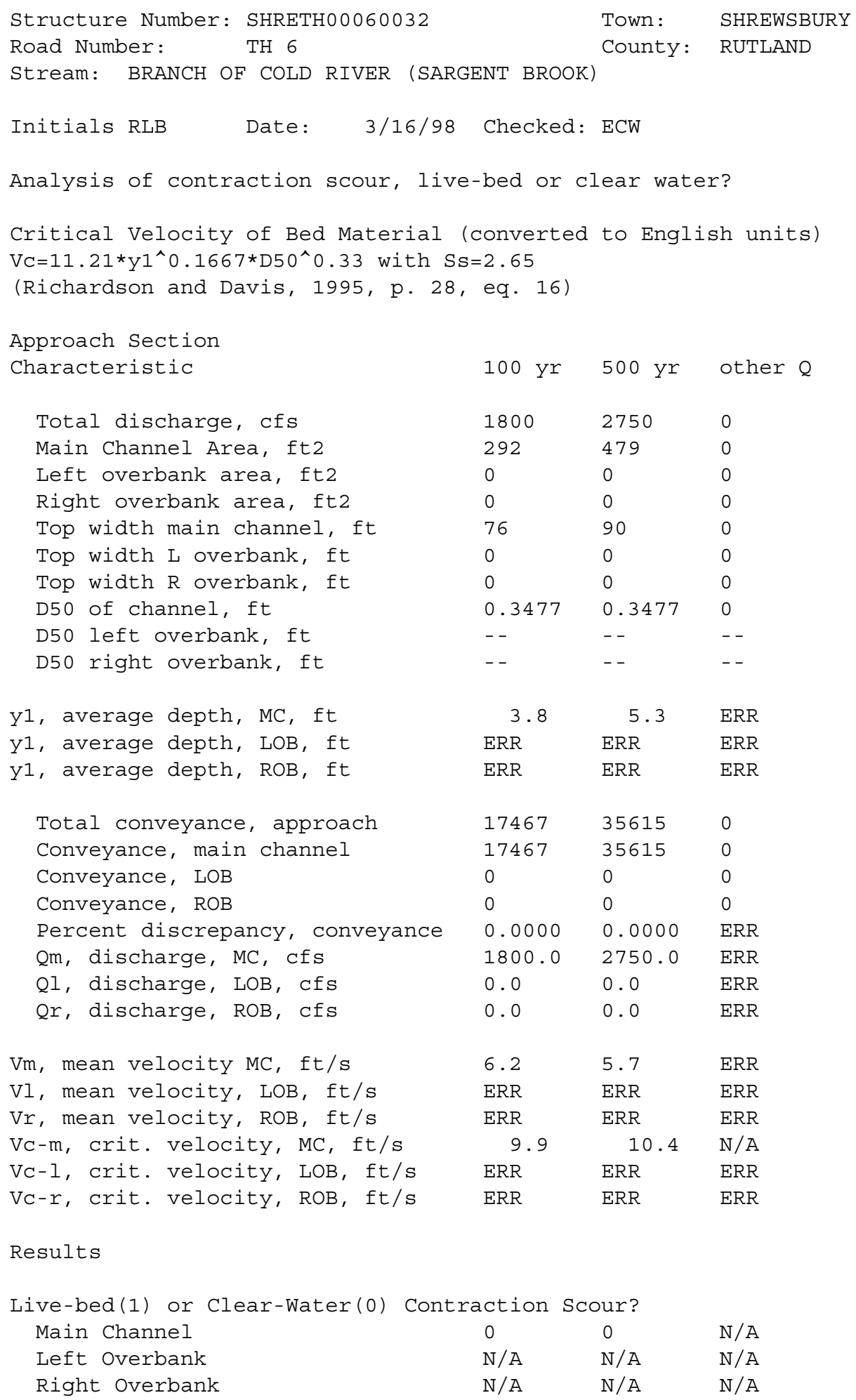

$\begin{array}{lll}0 & 0 & 0\end{array}$

$0 \quad 0 \quad 0$


Clear water Contraction Scour in MAIN CHANNEL

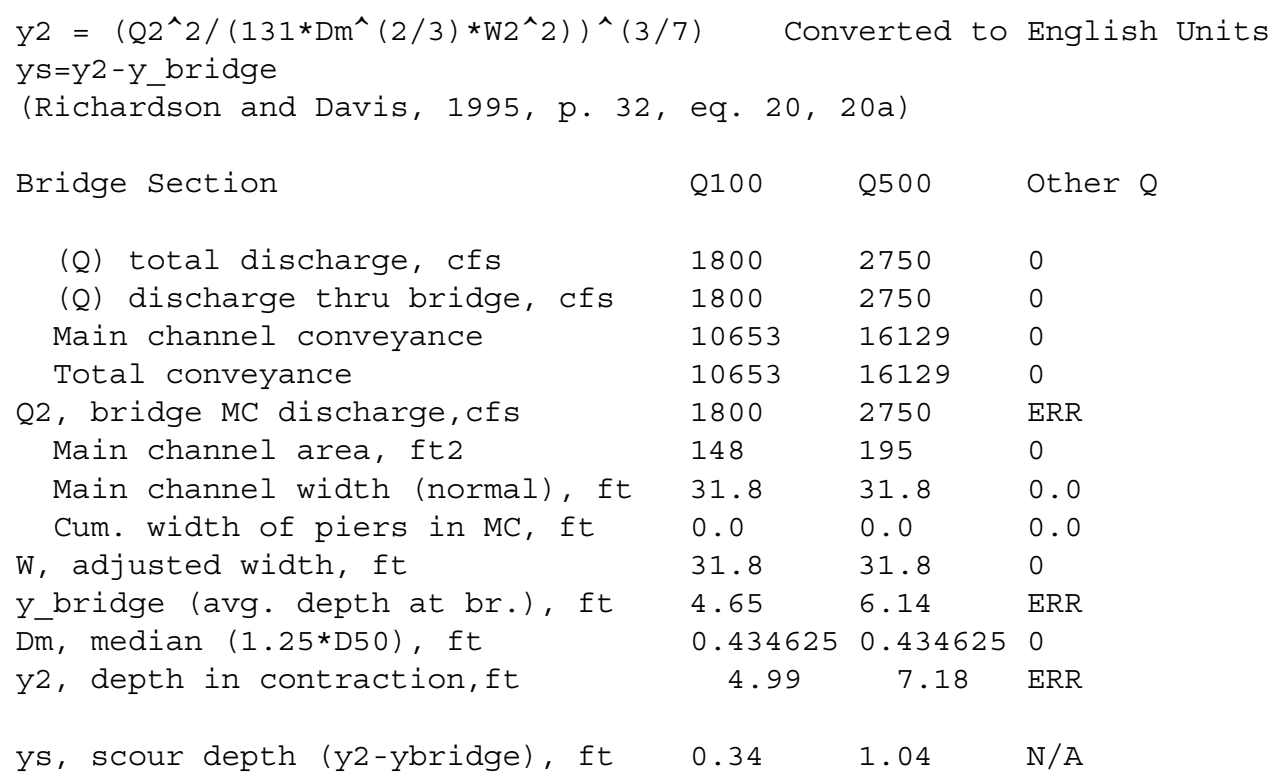

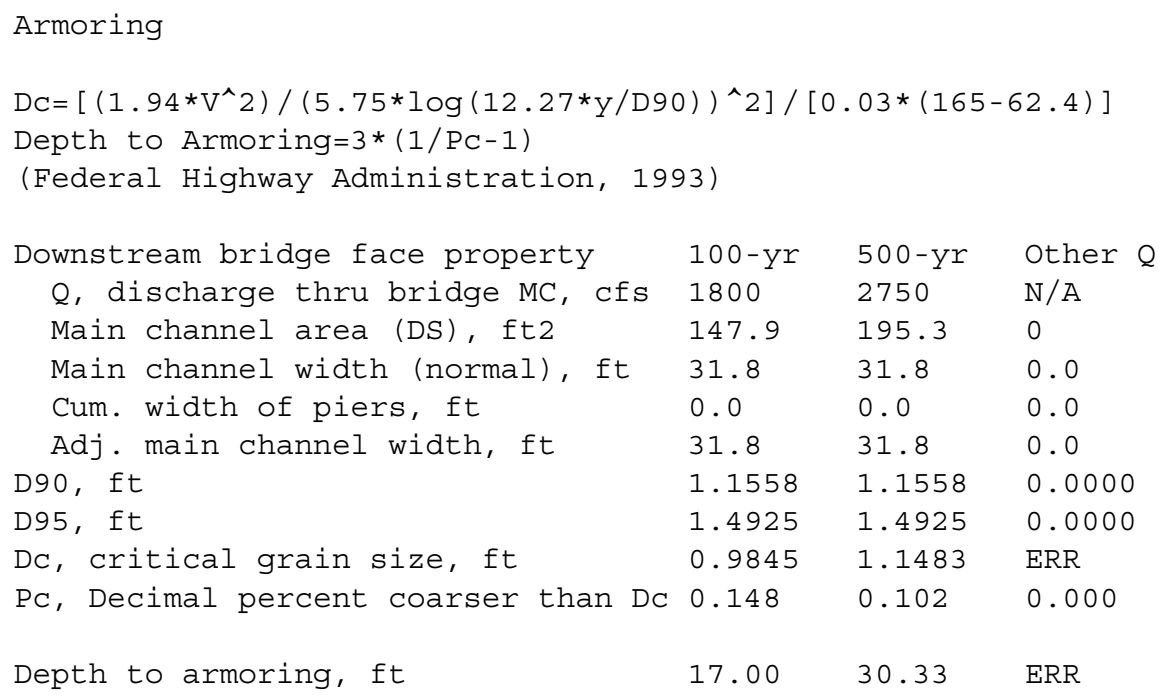


Abutment Scour

Froehlich's Abutment Scour

$\mathrm{Ys} / \mathrm{Y} 1=2.27 * \mathrm{~K} 1 * \mathrm{~K} 2 *\left(\mathrm{a}^{\prime} / \mathrm{Y} 1\right) \wedge 0.43 * \mathrm{Fr} 1 \wedge 0.61+1$

(Richardson and Davis, 1995, p. 48, eq. 28)

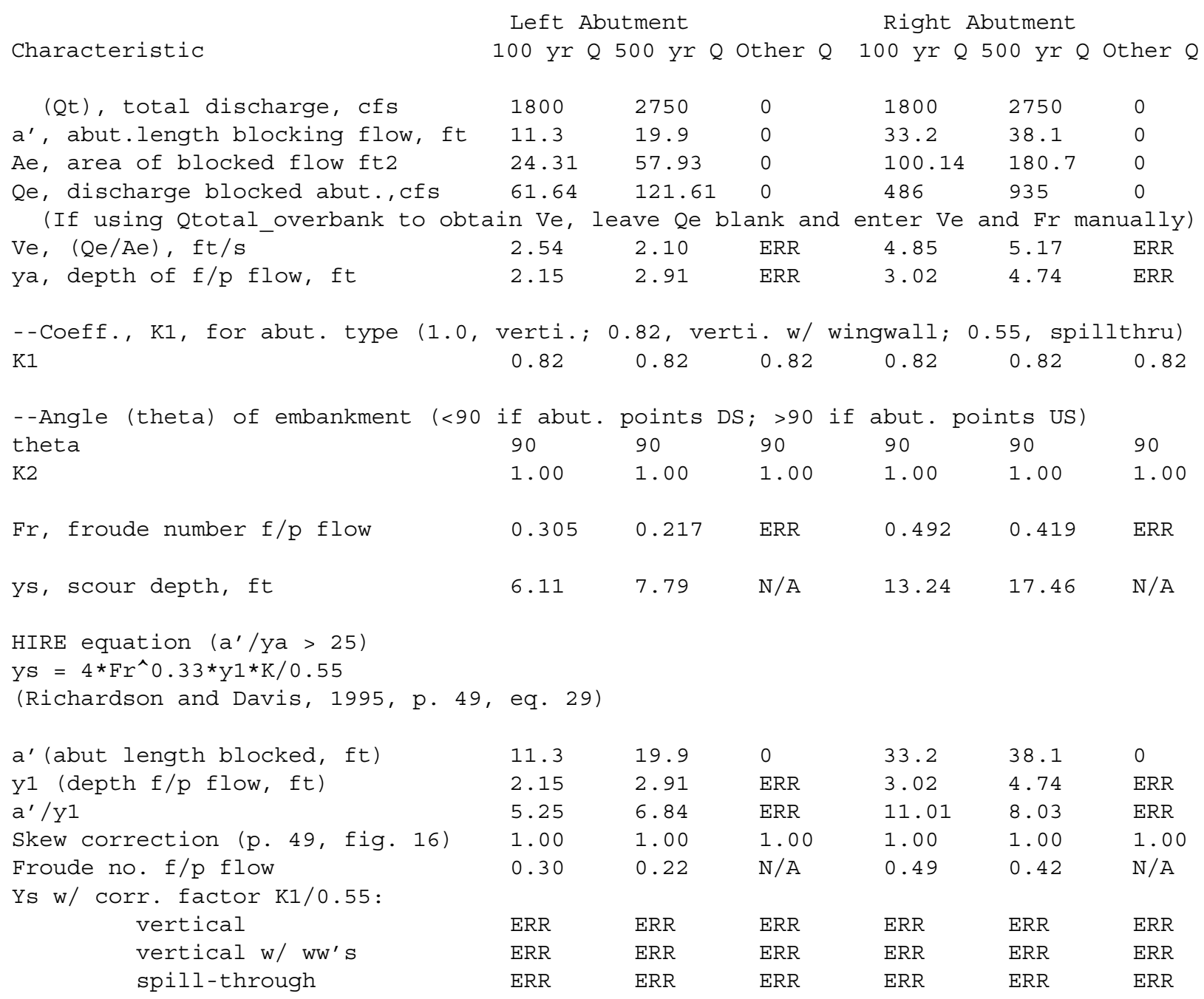




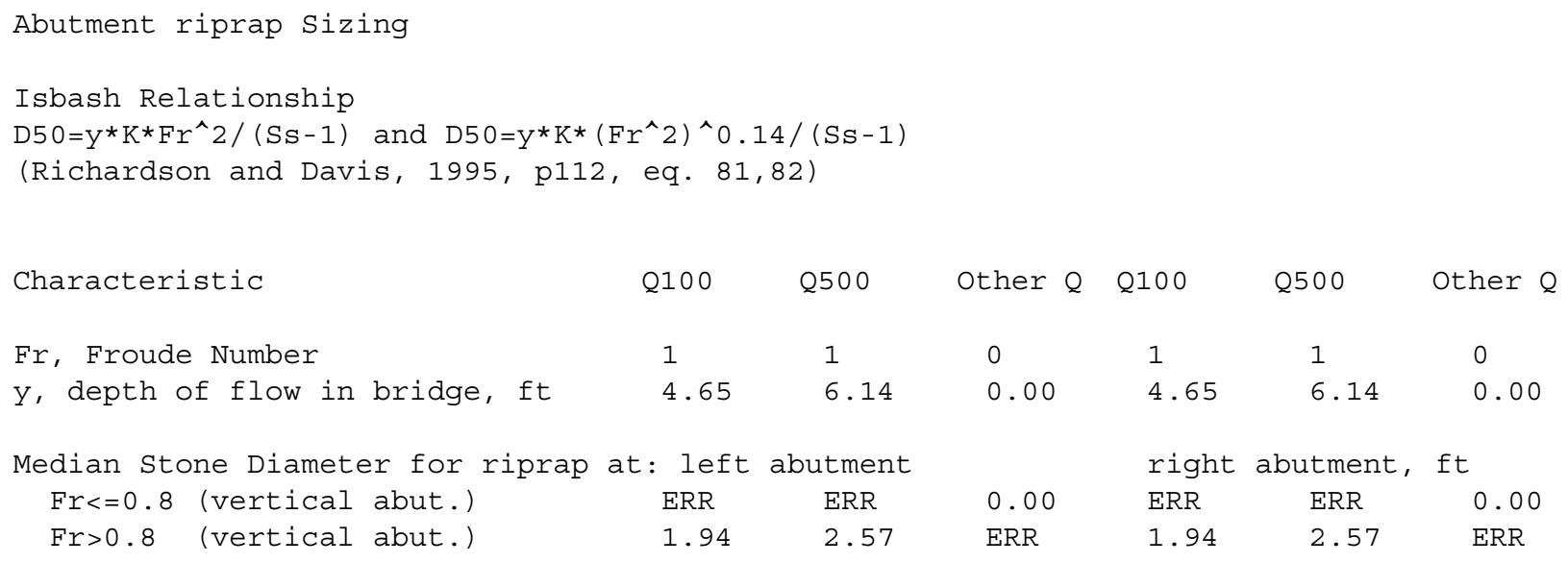

